\title{
PRENATAL NUTRITION AND THE RISK OF ADULT OBESITY: LONG-TERM EFFECTS OF NUTRITION ON EPIGENETIC MECHANISMS REGULATING GENE EXPRESSION
}

\author{
Running title: Epigenetic memory of gestational nutritional stress
}

\author{
Estanislau Navarro ${ }^{1, *}$,Anna N. Funtikova ${ }^{2,3,4}$, Montserrat Fíto ${ }^{2,5}$, Helmut \\ Schröder ${ }^{2,3}$
}

${ }^{1}$ Molecular Oncology Laboratory, Bellvitge Biomedical Research Institute (IDIBELL)

${ }^{2}$ Cardiovascular Risk and Nutrition Research Group (CARIN), IMIM (Hospital del Mar Medical Research Institute), Barcelona, Spain.

${ }^{3}$ CIBER Epidemiology and Public Health (CIBERESP), Instituto de Salud Carlos III, Spain

${ }^{4} \mathrm{PhD}$ candidate, Food and Nutrition program, University of Barcelona, Spain

${ }^{5}$ CIBER Physiopathology of Obesity and Nutrition (CIBEROBN), Instituto de Salud

Carlos III, Spain

*Author to whom correspondence should be addressed at:

Molecular Oncology Laboratory, Bellvitge Biomedical Research Institute (IDIBELL) Gran Via 199

L'Hospitalet de Llobregat

08908 Barcelona, Spain

Emails: estanis.navarro@gmail.com

Phone: +34932607339 
ABBREVIATIONS:

AS-RNA: antisense RNA

BAT: brown adipose tissue

BET: bromodomain and extraterminal

BMI: body mass index

CAD:coronary artery disease

CVD: cardiovascular diseases

DHA: docosahexaenoic acid

DMR: differentially-methylated region

DNMTs: DNA methyltransferases

DOAD:developmental origins of adult disease

DWF: Dutch Winter Famine

EGCG: (-)-epigallocatechin gallate

eRNAs: enhancer RNAs

ERV: endogenous retrovirus

GEN: genistein

HAT: histone acetyl transferase

HDAC: histone deacetylase

IAP: intracisternal A particle

IUGR: intrauterine growth retardation

I3C: indol-3-carbinol

LINE: long interspersed nuclear element

lncRNA: long non-coding RNA

LSS: Leningrad siege study

LTR: long terminal repeat

miRNAs: microRNAs

ME: metastable epiallele

NCD: non-communicable disease

NuRD: nucleosome remodeling and deacetylating complex

PASR/PALR: promoter-associated short RNAs/promoter-associated long RNAs

PcG: polycomb group protein

PRE: polycomb responsive element

PRC1/2: polycomb repressive complex

PTM: post-translationalmodification

SFN: sulforaphane

SGA: small for gestational age

T2D: type 2 diabetes

WAT: white adipose tissue 


\section{LIST OF GENES}

$\alpha$-MSH: $\alpha$-melanocyte-stimulating hormone

ABCA1: ATP-binding cassette subfamily A member 1

BRD2: bromodomain-containing 2 protein

CEBP- $\alpha / \beta / \gamma$ : CCAAT/enhancer binding protein- $\alpha / \beta / \gamma$

CDKN2 $\mathrm{A}^{\mathrm{p} 16}$ : cyclin-dependent kinase inhibitor $2 \mathrm{~A}$; CDKN2A

DNMTs: DNA methyltransferases

GLUT2: glucose transporter type 2

GNAS-AS: GNAS-antisense lncRNA gene

GR1-C: nuclear receptor subfamily 3 , group C, member 1 (glucocorticoid receptor)

IGF2: insulin-like growth factor II

IGF2R:insulin-like growth factor II receptor

INS-IGF2: INS-IGF2 readthrough lncRNA

IL-10: interleukin-10

JHDM1: lysine (K)-specific demethylase 2A

LEP: leptin

LDLRAP1: low-density lipoprotein receptor adapter protein 1

LSD1: lysine (K)-specific demethylase 1A (KDM1A)

HNF4A: hepatocyte nuclear factor $4 \alpha$

MEG3: maternally expressed 3 lncRNA

MLL1: mixed-lineage leukemia 1

MTA1: metastasis-associated protein 1

OGA: O-GlcNAcase

OGT: O-linked GlcNAc transferase

PDX1: pancreatic and duodenal homeobox 1

PI3K-p85: phosphatidylinositol 3 kinase-p85

PGC1 $\alpha$ : peroxisome proliferator-activated receptor gamma, coactivator 1 alpha

PLRL: prolactin receptor

PLZF: promyelocytic leukemia zinc finger protein

PPAR- $\gamma$ : peroxisome proliferator-activated receptor- $\gamma$

p15 ${ }^{\mathrm{INK} 4 \mathrm{~b}}$ : cyclin-dependent kinase inhibitor $2 \mathrm{~B}, \mathrm{CDKN} 2 \mathrm{~B}$

p16 ${ }^{\mathrm{INK} 4 \mathrm{a}}$ : cyclin-dependent kinase inhibitor 2A; CDKN2A

p21 ${ }^{\mathrm{WAF} 1 / \mathrm{Cip} 1}$ : cyclin dependent kinase inhibitor $1 \mathrm{~A}$; p21/WAF1

RUNX2: runt-related transcription factor 2

SIRT1: sirtuin 1

TET2/3: (ten-eleven translocation 2/3) methylcytosine dioxygenase

UCP1: uncoupling protein 1

WIF1: Wnt inhibitory factor 1

ZEB1: zinc finger E-box binding homeobox 1 


\title{
KEYWORDS:
}

nutrient sensors, gestational programming, nutrition, epigenetic memory, OGlcNAcylation, regulatory exhaustion.

\begin{abstract}
Solid epidemiological evidence indicates that part of the risk of obesity in adulthood could be programmed during prenatal development by the quality of maternal nutrition. Nevertheless, the molecular mechanisms involved are mostly unknown, which hinders our capacity to develop effective intervention policies. Here, we discuss the hypothesis that mechanisms underlying prenatal programming of adult risk are epigenetic and sensitive to environmental cues such as nutrition. While the information encoded in DNA is essentially stable, regulatory epigenetic mechanisms include reversible, covalent modifications of DNA and chromatin, such as methylation, acetylation etc. It is known that dietary availability of methyl donors has an impact on the patterns of gene expression by affecting DNA methylation at regulatory regions, a likely basis for reprogramming developmental plasticity. The Agouti and Axin-fused genes, as well as the embryonic growth factor IGF2/H19 locus are examples of diet-induced modulation of phenotypic traits by affecting methylation of gene-regulatory regions. Furthermore, recent work has evidenced an unsuspected role for chromatin as metabolic sensor. Chromatin is susceptible to a number of post-translational modifications that modulate gene expression, among them the GlcNAcylation of histone proteins and other epigenetic regulators. Intracellular levels of the precursor molecule UDP-GlcNAc, and hence the degree of global chromatin GlcNAcylation, depend on the energetic state of the cell, making GlcNAcylation a functional link between nutrition and regulation of gene expression. Dietary interference with these regulatory mechanisms could effectively counteract the early-life programming of adult risk.
\end{abstract}




\section{INTRODUCTION}

Obesity and related conditions are currently explained by a linear view of disease progression, in which expansion of white adipose tissue (WAT) generates a proinflammatory microenvironment that spreads through organs and tissues, hindering their function and causing the devastating comorbidities associated with obesity. This model can be refined by adding genetic predispositions and factors linked to lifestyle, such as diet or exercise, that influence the onset and progression of obesity and obesityrelated conditions (see $[1,2]$ for recent reviews). In this way, obesity, although modulated by genetic predispositions, could be considered as an "acquired" environmental disease to be treated by targeting causative elements such as defective or excessive nutrition or sedentary lifestyle.

In recent years, however, the concept of obesity as an "epigenetic disease" has begun to be discussed. According to this perspective, environmental impacts on maternal nutrition during early embryo life leave a "nutritional imprint" with long-term effects on the promotion of obesity and related conditions in adulthood [3]. The present review addresses the hypothesis that adult obesity and related conditions may be programmed, at least in part, very early in life, focusing special attention on the recent explosive increase in the availability of data on epigenetic regulation and modification (DNA methylation, histone modifications, and non-coding RNAs). Here, we review recent literature on the epigenetic mechanisms putatively involved in programming the long-term effects of early-life nutrition, and how these could be modulated by environmental/nutritional cues.

Nutrition can affect the expression of a number of genes by its impact, in the form of methyl donors such as folate, on the degree of methylation of their regulatory regions, althoug folate supplementation could also have some undesired consequences on the stability of the epigenome. In the present review, we especially highlight recent reports that underscore a role for chromatin as a metabolic/nutrient sensor through the post-translational modification of histone proteins, which links regulation of gene expression to availability of nutrients and metabolites from the intermediary metabolism (see [4] for a recent review). 


\section{LONG-TERM EFFECTS OF EARLY-LIFE NUTRITION ON OBESITY AND OBESITY-RELATED RISK FACTORS}

\subsection{Long-term effects of fetal/neonatal malnutrition on adult risk factors}

Sound epidemiological evidence has shown that malnutrition in early life not only affects fetal/neonatal growth but also has long-term consequences for adult health. Almost a century ago, Kermack, McKendrick and McKinlay hypothesized that the first 15 years of life influence the lifelong health of the individual [5], while Forsdahl demonstrated a significant association between infant mortality in the early years and adult mortality(ages 40-69 years) by coronary artery disease (CAD), and concluded that "great poverty in childhood and adolescence, followed by prosperity, is a risk factor for arteriosclerotic heart disease" [6]. Similarly, Barker and Osmond evidenced a consistent, positive correlation between infant mortality in 1921-1925 and ischemic heart disease mortality rates in 1968-1978 in England and Wales [7], results confirmed by their further work showing a strong positive correlation between low weight at birth and at one year of age and rates of CAD death in adulthood [8]. Several additional hypotheses have been proposed. The idea that growth impairment at conception or during fetal development could be linked to a number of chronic adult diseases, such as CAD [7], glucose intolerance [9], type 2 diabetes (T2D) [10], or obesity and hypertension [11] is known as the "developmental origins of adult disease" (DOAD) hypothesis [3]. This challenges the consideration of the womb as a highly protective milieu that buffers the embryo from environmental stressors, and acknowledges that the embryo is sensitive to outside stimuli and that the prenatal period is critical for modulating long-term disease predisposition by reprogramming the developmental plasticity of the embryo, likely by selectively impairing cell differentiation and organ growth $[12,13]$. The thrifty phenotype hypothesis states that fetal undernutrition will cause the embryo to prepare for a life of scarcity, but subsequent accelerated overgrowth (catch-up) in conditions of affluence in the early post-natal period could overcome these protective barriers, facilitating fat deposition, obesity, and obesityrelated conditions $[10,14]$. Fetal/neonatal overnutrition could have similar long-term effects on health ([15] and references therein), as reported for infants who are large for their gestational age when born to mothers with diabetes [16], indicating that postnatal fast weight gain could be the critical factor explaining their increased risk for cardiovascular diseases (CVD) [17]. This idea has been supported by the results of two 
prospective trials in which randomly assigned cohorts of small-born infants were fed either a nutrient-enriched formula or a control formula, which showed that the nutrientenriched diet increased fat mass later in childhood [18].

\subsection{Historical cohorts to study the association of early nutrition and later disease.}

Well-documented historical episodes of hunger have been used to study the association between prenatal nutritional stress and the risk for adult chronic diseases[19], with the first demonstration coming from the cohort of people affected by the Dutch Winter Famine of 1944-1945 (DWF) [20]. Beginning in October 1944, civilian transport in the western part of Holland was totally blocked by the German Army, causing a dramatic shortage in food supply and a subsequent reduction in the daily rations, which reached their lowest value (400-800 Kcal/per person/day) between December 1944 and April 1945. Upon the end of the war, the blockade was raised and daily rations soon reached normal pre-war values [21]. The DWF cohort includes the original inhabitants of the blocked areas well as their descendants born around the time of hunger, who have been stratified by famine exposure at the first, second, or third trimester of fetal development [21]. In the current DWF population older than 50 years, a number of studies have linked prenatal famine exposure with numerous characteristics: decreased fetal growth and reduced tolerance to glucose in adulthood (especially when exposure occurred at late gestation [22]); higher BMI and waist circumference, in women but not in men [23]; a more atherogenic lipid profile [24], and obesity, but only when exposure was during the first trimester of pregnancy [20, 21], an effect that affected up to the third generation [25]. Furthermore, prenatal famine exposure has been related with increased risk of T2D [26], overall adult mortality in women [27], and CAD [28, 29], although other authors have failed to find this association between prenatal famine exposure and adult CAD [30, 31] (see Table 1 for a summary of the long-term effects of fetal nutritional stress on obesity-related risk factors).

The Leningrad Siege Study (LSS) also investigated the relationship between maternal malnutrition and risk factors in adult offspring. The siege of Leningrad (now St. Petersburg) by the German Army for almost three years (September 1941-January 1944) resulted in more than one million deaths, mainly of starvation due to daily rations of only 300 calories during the worst of the siege [32]. The LSS results contradicted but complemented those of the DWF study, showing no associations between 
intrauterine/infancy starvation and glucose intolerance, dyslipidemia or CVD risk later in adulthood [32, 33], even 70 years after the end of the siege [34], probably because the LSS population had no catch-up period of accelerated growth in early childhood, but rather lived in harsh conditions until the end of the siege [35]. This suggests that a period of postnatal nourishment must be relevant in determining the impact of maternal malnutrition on future health [36].

Striking evidences indicate that disease predisposition could be transferred to successive generations. The cohort of people born in Överkalix parish in northern Sweden at the turn of the 20th century showed a direct association between food availability up to the puberty of grandparents and parents and mortality due to CVD and T2D in the grandsons [37]; cardiovascular mortality was linked to the father's nutritional status and diabetes to the paternal grandfathers' [38]. Furthermore, sharp changes in food supply up to the puberty of paternal grandmothers increased CVD mortality of their sons' daughters [39]. The DWF cohort also has been studied in the context of the transgenerational effects of prenatal exposure to famine, assessing the health of the children (F2) of parents born during the famine (F1) to undernourished women (F0). In one such study, an increase in body mass index (BMI) was found in F2 of F1 fathers, but not F1 mothers, when compared with offspring of control (not famineexposed) fathers [25]. The authors did not find significant differences in the prevalence of $\mathrm{CAD}, \mathrm{T} 2 \mathrm{D}$, high cholesterol, or hypertension in the $\mathrm{F} 2$ of exposed parents compared to the F2 of unexposed parents [25]. Similarly, Painter et al. detected an increase in neonatal adiposity and poor adult health in the F2 of F1 women exposed "in utero" to F0 famine, but did not find transgenerational impacts of famine exposure on the F2 rates of CAD or T2D in offspring of the exposed F1 [40]. Nevertheless, this F2 cohort is still young (mean age 37 years) and rates of chronic diseases could increase in the future in this group [25].

\section{EPIGENETICS: THE NEXT FRONTIER IN THE REGULATION OF GENE EXPRESSION}

\subsection{Challenging dogmas on genome structure and function}

Recent years have seen a paradigm change in ideas about the flow of genetic information. The original linear model, "DNA makes RNA makes protein”, for many years considered the central dogma of molecular biology [41, 42], has been replaced by 
a multilayered process characterized by the pervasive expression of many different (Figure 1). International sequencing efforts have shown that the human genome is composed of just 20,000 to 25,000 protein-coding genes [43-45], with a best-guess estimate of 22,333 [46], a figure that would account for a mere $2 \%$ of the total genome length [47] and far fewer than the 100,000-120,000 protein-coding genes previously estimated [48-50]. Nevertheless, the number of transcriptional units could exceed 60,000 [51] by including a plethora of previously unclassified non-protein-coding RNAs, such as microRNAs (miRNAs), antisense-RNAs (AS-RNAs), promoterassociated RNAs (PALRs, PASRs), other long non-coding RNAs (lncRNAs), etc. [5254]. Recent data suggest that approximately $80 \%$ of the genome could be considered biochemically active [55], most of it in the form of DNase I-accessible loci or candidate regulatory sequences [56-58]. Taken together, all these data draw a new image of the eukaryotic nucleus in which the genome would be pervasively transcribed, even in intronic and intergenic sites [59], with protein-coding genes encoding additional transcriptional units for a complex population of short and long non-coding RNAs with putative regulatory functions [60].

\section{2 microRNAs and long non-coding RNAs:new actors on the gene-regulation} stage

MicroRNAs (miRNAs) are small RNAs (over 22 nucleotides long) with important roles in post-transcriptional gene regulation. MiRNAs are transcribed as primiRNA precursors; after two processing steps, they generate the mature miRNAs, which are subsequently exported to the cytoplasm where they associate to their target mRNAs and induce their degradation or interfere with their translation (see [61] for a review). As of March 2016, the entire human miRNAome was described as formed by 1881 precursors and 2588 mature miRNAs (www.mirbase.org, mirbase release 21 [62]). MiRNAs are highly promiscuous, so that a single miRNA can interact with a number of different mRNAs which in turn can be regulated by several different miRNAs [63]. Aberrant miRNA expression profiles have been linked to a number of human diseases, such as leukemias [64], solid tumors [65], atherosclerosis and CVD [66, 67], chronic pain [68], and renal fibrosis [69], among others. Alterations in the expression of miRNAs have been detected not only in the primary tissue but also in blood [70], urine 
[71], and exosomes [72], and miRNAs (or miRNA-targeting sequences) are currently being tested for therapy development [73].

The family of lncRNAs constitutes an extremely heterogeneous population of functionally unrelated RNAs longer than 200 nucleotides, which have important roles in development, differentiation, and disease [74-76]. Currently estimated at more than 56.000 [77], the number of lncRNAs more than doubles the number of protein-coding genes in the human genome, thus giving a hint of their functional complexity. Most of the lncRNAs are natural antisense transcripts, transcribed from the complementary chain of target genes, which likely cis-regulate its genomic locus by recruiting the histone-modifying machinery to the regulatory regions of the target genes [78]. Another common family of lncRNAs is the enhancer RNAs (eRNAs) or lncRNAs transcribed from functional enhancer sequences and associated to specific histone marks (high H3K4me1, H3K4me2, and H3K27ac and low H3K4me3 and H3K27me3) which could have a role in the activation of genes $[79,80]$, probably by facilitating the long-distance interaction of enhancers and their cognate promoters by forming or stabilizing DNA loops [81].

\subsection{Methylation of DNA and histones, and the regulation of gene expression}

Genes are precisely regulated by controlling access of the transcriptional machinery to their regulatory regions (promoters or enhancers). This process is mediated by the covalent modification of regulatory DNA sequences, mainly by methylating cytosines from $\mathrm{CpG}$ dinucleotides at position 5 through the activity of the family of DNA methyltransferases (DNMTs), which transfer a methyl group from Sadenosyl-methionine (SAM) to the cytosine [82]. CpG pairs concentrate in proximal (CpG islands) or distal ( $\mathrm{CpG}$ shores) parts of the gene promoter, and in the methylated form are usually associated to gene silencing, although they are also involved in parental imprinting (see [83] for a review). Patterns of $\mathrm{CpG}$ methylation are strictly regulated and stable, and their alterations have been associated to diverse diseases, including cancer.

The function of histones in chromatin is also subjected to epigenetic regulation. Histones have protruding $\mathrm{N}$-terminal and $\mathrm{C}$-terminal tails that expose many positively charged aminoacids $(\mathrm{K} / \mathrm{R})$, which modulate the interaction with other histones and with the negatively charged DNA [84]. Histone modifications (known as tags or marks) contribute to the regulation of gene expression by changing the net charge of histone 
proteins in order to regulate the strength of their interaction with DNA (and hence its accessibility) and by providing docking sites for the interaction of components of the transcriptional machinery [85] (see the description of the histone-tag nomenclature at the legend of Table 2). Aminoacids in the protruding histone tails are susceptible to many different covalent modifications "in vivo", such as methylation, acetylation, ribosylation, phosphorylation, ubiquitination, sumolation, biotynilation, and more than 50 different tags [86, 87]. Furthermore, the existence of numerous histone genes, which generate up to 57 histone variants of differing lengths and sequences in humans, greatly increases the number of aminoacids susceptible to modification ([88]).

The stability of epigenetic marks is critical to control the long-term effects of events that alter the epigenetic landscape. While the genetic information encoded in DNA can be regarded as essentially stable, epigenetic marks are reversible and respond to endogenous, as well as environmental (nutritional, social, hormonal, cultural) stimuli. These dynamic modifications are "interpreted" by a number of families of epigenetic regulators [89] that have been classified as "tag-writers" (histone methyltransferases and acetyltransferases) [90], "erasers" (histone demethylases and deacetylases), or "readers", proteins that include domains of the plant, chromo, Tudor, or MBT families, among others, and recognize different tagged histones (see [91] for a recent review). Elucidating the mechanisms that promote, maintain, read, and erase epigenetic marks is currently an area of intense research aiming to develop small molecules able to modulate expression of disease-associated genes at the epigenomic level [92].

\section{REGULATION OF GENE EXPRESSION BY FOLATE AVAILABILITY: THE agouti, axin-fused AND IGF2/H19 LOCI}

As reported above, the DWF cohort evidenced a number of risks in adulthood that could be traced to specific periods of embryonic development during which the mother experienced nutritional stress. A likely explanation for this finding was that the stress burden could affect (reprogram) the expression of genetic loci critical for embryo development. In this sense, recent work has evidenced that the folate-dependent methylation of DNA regulatory sites constitutes a direct link between nutrition and regulation of gene expression. In this section we review data on the effects of folate availability on the regulation of gene expression in two animal models, the agouti and 
axin-fused loci, and in the human $I G F 2 / H 19$ locus, a complex genetic structure involved in the control of early embryo development.

\subsection{Genomic structure of the agouti $\left(A^{v y}\right)$, axin-fused $\left(A x i n^{F u}\right)$ and IGF2/H19loci}

Agouti mice show a characteristic yellow coat because the protein encoded by the agoutigene (ASP, for agouti signaling peptide) blocks eumelanin synthesis in hair follicles [93]. Interestingly, the "viable yellow" $\left(A^{v y}\right)$ allele, a mutation in the agouti gene due to the insertion of a partial long terminal repeat (LTR) of an intracisternal A particle (IAP) retrotransposon, prompts the ubiquitous expression of the agouti gene because this LTR functions as a non-tissue-specific cryptic promoter $[94,95]$. The $A^{v y}$ allele is epigenetically unstable and can lose methylation at the LTR so that heterozygous $\left(A^{v y} / a\right)$ mice, which also carry the recessive null (a) allele for a black coat, display continuously variegated agouti fur depending on the methylation status of the cryptic promoter, ranging from yellow in mice with a demethylated promoter to obscure-agouti/pseudoagouti fur in mice with an overmethylated promoter [96]. These methylation patterns are randomly fixed early in embryonic life and are maintained throughout life [97].

Similarly to the agouti gene, the $\operatorname{axin}^{F u}$ locus derives from the insertion of an intracisternal A particle (IAP) retrotransposon, in this case in the intron 6 of the axin gene. This insertion generates a number of aberrant axin transcripts, some of them using the 3' LTR of the IAP as a cryptic promoter [98]. The wild-type AXIN protein controls the formation of embryonic axis by repressing Wnt signaling [99]. Work by Rakyan and cols. showed that hypomethylation of the cryptic promoter (IAP) of the Axin ${ }^{F u}$ allele caused the upregulation of AXIN expression, with the subsequent downregulation of Wnt activity that resulted in kinking of the distal tail [100]. On the other hand, the parentally imprinted IGF2/H19 human locus encodes the insulin-like growth factor II (IGF2) gene, which promotes embryo and placental growth [101] and is expressed almost exclusively from the paternal chromosome [102], as well as the maternally expressed lncRNA-H19, which limits the growth of the placenta through the regulated processing of miR-675 that is embedded in the first exon of the $H 19$ gene [103]. The IGF2/H19 locus includes an intergenic, CpG-rich, differential methylation region (DMR) as well as a distal enhancer region, immediately downstream of the H19 gene, which together drive the tissue-specific, allele-restricted, and developmentally confined expression of the IGF2 and H19 genes [104] (Figure 2). The intergenic DMR 
regulates $I G F 2 / H 19$ gene expression; its demethylated form (maternal allele) recruits the regulatory factor $\mathrm{CTCF}$, which functionally blocks the downstream enhancer, repressing the growth-promoting effect of the IGF2 gene and activating the growth-limiting H19 gene. In contrast, methylation of the intergenic DMR (paternal allele) allows the enhancer to activate the IGF2 promoter while repressing the $H 19$ gene. In this way, the degree of intergenic DMR methylation acts as a balance, promoting (through IGF2 expression) or limiting (through H19 expression) early embryonic growth [105].

\subsection{Folate availability regulates expression of the viable yellow agouti $\left(A^{v y}\right)$ and axin-fused $\left(\right.$ Axin $\left.^{F u}\right)$ loci.}

Chromatin-methylating enzymes, i.e., DNA and histone methyltransferases, use S-adenosylmethionine (SAM) as universal methyl donor and folate to regenerate SAM through the one carbon metabolism pathway [106], suggesting that folate is an important component of the gene regulatory machinery. Folate deficiencies have been acknowledged as the basis of many nutrition-related diseases [107, 108], which supports this hypothesis and highlights folate as a critical link between nutrition and gene expression. This relationship has been evidenced by work with agouti and axin-fused model mice. Thus, in agouti mice, supplementation of $(a / a)$ dams with a methyl-rich diet shifted the coat color of the $A^{v y} / a$ offspring from yellow to the brown pseudoagouti [109], a result also seen after supplementation of $(a / a)$ dams with genistein, a major soy isoflavone [110]. In both cases, the phenotypic shift coincided with an increased methylation of the IAP insertion region at the agouti locus in the pups [111].

Change in coat color is not the only phenotypic trait associated to the agouti locus. Heterozygous mice harboring the lethal yellow $\left(A^{y}\right)$ or viable yellow $\left(A^{v y}\right)$ mutations showed a number of pleiotropic effects, including obesity, increased tumor susceptibility, and embryonic lethality [112]. The obesogenic role of the $A^{v y}$ allele was due to the agouti gene product, the agouti-signaling peptide (ASP), since a transgene overexpressing $\mathrm{ASP}^{\mathrm{wt}}$ induced obesity in the recipient mice [113] and incubation of mature 3T3-L1 adipocytes with recombinant ASP increased expression of adipogenic transcription factors [114]. Interestingly, this obesogenic effect proved to be sensitive to dietary supplementation with methyl donors or with genistein, which reversed the effect of the $A^{v y}$ allele by overmethylating its cryptic promoter [110, 115]; this constitutes experimental evidence of a dietary modification in pregnant mothers that directly affects the obese phenotype of the offspring. 
On the other hand, in the case of the Agouti locus, supplementing Axin ${ }^{F u}$ dams of the $\operatorname{Axin}^{F u}$ locus and reduced the incidence of tail kinking in their offspring [116]. Nevertheless, the mechanisms involved in this nutrient-induced methylation of regulatory regions are complex and must include numerous (epi)genetic factors to accurately control the expression of Agouti or Axin-fused genes [117]; Dolinoy et al. showed that yellow agouti mice had less repressive histone tag H4K20me3 in the LTR of the IAP, compared to their pseudoagouti littermates [118].

\subsection{The Dutch Winter Famine caused life-long alterations in the methylation pattern of the IGF2/H19 locus in the offspring of affected pregnant mothers}

In an experimental study, Heijmans et al. studied the methylation pattern of the IGF2-DMR in the DWF cohort of individuals conceived during the Dutch famine. Six decades after being exposed to the famine, the IGF2-DMR was hypomethylated (see Figure 2), compared with their non-exposed siblings, when the exposure was periconceptional but not when individuals were exposed late in gestation, suggesting that early-life nutritional stress had an impact on the methylation pattern of the IGF2/H19 locus, and that this altered pattern could be maintained for decades until adulthood [119]. Furthermore, the degree of methylation of the IGF2-H19 locus was directly associated with fetal and infant growth, with children born small-for-gestational age (SGA) showing a decreased level of IGF2-DMR methylation in white blood cells obtained from umbilical cord, compared with control children [120]. On the other hand, Steegers-Theunissen et al. showed that periconceptional supplementation of pregnant mothers with $400 \mu \mathrm{g}$ of folic acid significantly increased methylation at the IGF2-DMR locus of the child, compared with the offspring of non-supplemented mothers; however, the authors also found an inverse association between IGF2-DMR methylation and birth-weight that is difficult to explain by the current models of regulation of the IGF2H19 locus but that could indicate involvement of other genomic loci [121].

Other loci related to growth and metabolism also have been studied. Those encoding interleukin-10 (IL-10), leptin (LEP), ATP-binding cassette subfamily A member $1(A B C A 1)$ or the lncRNAs maternally-expressed 3 (MEG3) and GNASantisense $(G N A S-A S)$ were found to be overmethylated in the famine-exposed individuals vs. non-exposed siblings, while the INS-IGF2 IncRNA, also at the IGF2 locus, was found to be undermethylated. This result further supports the hypothesis that 
early-life nutritional stress could cause widespread alterations in DNA methylation [122]. A genome-wide analysis of DMRs in the DWF cohort detected a number of differentially methylated $\mathrm{CpG}$ elements-such as enhancers, open chromatin regions, and developmental enhancers- associated to the prenatal famine, usually at regulatory regions, suggesting that they could influence the expression of many different genes and especially of genes linked to metabolism and growth [123]. On the other hand, the promoters of the glucocorticoid receptor $G R I-C$, peroxisome proliferator-activated receptor gamma $(P P A R-\gamma)$ lipoprotein lipase, or phosphatidylinositol 3 kinase p85 (PI3K-p85) did not differ in their degree of methylation in the blood of individuals exposed "in utero" to famine, compared to non-exposed controls [124], suggesting that the nutrition-dependent changes in methylation could be gene- or tissue-restricted.

\section{EPIGENETIC REPROGRAMMING OF DEVELOPMENTAL PLASTICITY: ADIPOSE TISSUE AND PANCREAS}

The interventional or longitudinal studies described above have clearly established that nutrition can modulate the global levels of methylation at generegulatory regions. Nevertheless, this top-down approach (from nutrition to gene expression) has produced very scanty data on the specific genes or gene networks de/methylated, so that it is difficult to delineate the mechanisms linking overall nutrition-dependent epigenetic alterations with increased adult risk of noncommunicable diseases (NCDs). An alternative to the top-down approach appeals to the phenotypic plasticity of tissues and organs at critical periods of early embryo development (mainly to control stem cell proliferation and/or cell differentiation) to determine whether the expression of the genes controlling these processes could be modulated by external stimuli. In this chapter, we discuss recent work on genes important to the development of organs and systems that maintain metabolic homeostasis, such as the pancreas and the adipose tissue, and whose expression has been shown to be modulated by nutritional cues.

\subsection{Maternal malnutrition affects the epigenetic regulation of pancreas development.}

Pancreatic and duodenal homeobox 1 (PDX1) is a transcription factor that is essential for the survival and function of the mature pancreatic $\beta$-cells, to the extent that disruption of the $P d x l$ gene $\left(P d x l^{-/-}\right.$mice) results in the arrest of pancreatic 
development at an early embryonic stage [125]. Adult expression of PDX1 has been growth retardation (IUGR), which predisposes to T2D development in adulthood, Park et al. showed that the $P d x l$ gene underwent epigenetic modifications that downregulated $P d x 1$ expression in $\beta$-cells from over 50\% (vs. control) in IUGR fetuses to null values in adults [126]. Furthermore, the authors were able to map this regulatory behavior to a region of the $P d x 1$ proximal promoter that included a $\mathrm{CpG}$ dinucleotide in a binding site for the USF-1 transcription factor, which was progressively methylated in IUGR rats but not in control animals. Methylation of the $P d x l$ proximal promoter was accompanied by histone deacetylation, since inhibition of HDAC partially restored $P d x 1$ expression [126]. Similar results have been recently described by Abuzgaia et al., who used a rat model of gestational maternal protein restriction, which increases susceptibility to T2D. In a low-protein group, they detected downregulation of $P d x I$ mRNA and protein expression, as well as of its downstream target genes insulin and glucose transporter Glut2, compared with controls [127]. Furthermore, a genome-wide analysis of CpG-methylated sites made in pancreatic islands from IUGR rats showed that changes in cytosine methylation in over 1400 loci preceded the development of $\mathrm{T} 2 \mathrm{D}$, giving a hint about the number of loci potentially involved in the pathogenesis of this disease [128], while a high-throughput analysis of gene expression led to the detection of 253 differentially expressed genes in the livers of exposed vs. non-exposed offspring, among them many encoding enzymes related to fat metabolism and potentially involved in the development of metabolic diseases [129].

Diet-induced changes in the levels of histone tags also have been described in a number of developmentally important genetic loci. Maternal low protein diets have been associated to downregulation of mRNA and protein expression of the tumor suppressors CDKN2A $\mathrm{A}^{\mathrm{P} 16}$ and $\mathrm{p} 21^{\mathrm{WAF} 1 / \mathrm{Cip} 1}$ in the mammary glands of offspring, concomitant with a reduction in acetylated $\mathrm{H} 3$ and in $\mathrm{H} 3 \mathrm{~K} 4 \mathrm{me} 2$ in their promoter regions [130, 131]. In a rat model of gestational maternal protein restriction, Sandovici et al. showed the downregulation of Hnf4a, a transcription factor gene critical to pancreatic function, in the islets of the exposed pups, compared with control pups, as well as an increase in the repressive tag $\mathrm{H} 3 \mathrm{~K} 9 \mathrm{me} 2$ and a decrease in the active mark H3K4me1 in the Hnf4a intronic enhancer, with a subsequent reduction in its interaction with the Hnf4a promoter [132]. 


\subsection{Maternal malnutrition affects the regulation of adipogenic genes.}

The adipose tissue of an adult organism is mainly composed of white adipose tissue (WAT) plus some remnants of the thermogenic brown adipose tissue (BAT). WAT has a double physiological role as regulator of the body's energy balance and as an endocrine organ that controls a number of physiological and pathophysiological mechanisms through the release of hormones and adipokines. This highly dynamic tissue adapts to external stimuli by increasing the number or size of adipocytes (see [133] for a recent review). Preadipocyte differentiation is controlled by the early transcription factors $\mathrm{C} / \mathrm{EBP}-\beta$ and $\mathrm{C} / \mathrm{EBP}-\gamma$, which regulate $P P A R$ and $C / E B P-\alpha$, adipogenic master genes that promote adipocyte terminal differentiation through their ability to activate the expression of adipocyte-specific genes (see [134] for a recent review). Among the genes activated by PPAR- $\gamma$ are many involved in lipid metabolism and insulin/IGF signaling [135], as well as the uncoupling protein-1 (UCP1), a functional marker for BAT whose mRNA peaks soon after birth in large mammals and then is rapidly lost, together with its transcription activating factors PPAR $\alpha$ and coactivator PGC-1 $\alpha$, as part of a developmental switch from BAT to WAT [136].

Prenatal undernutrition has been shown to have an impact on the fetal fat mass as well as in the expression of UCP1 mRNA. In this regard, ovine maternal nutrient restriction during the early gestation resulted in offspring with more adipose tissue and higher levels of $U C P 2$ and PPAR $\alpha$ mRNAs than unrestricted controls, while no changes were detected in the levels of UCP1, PPAR- $\gamma$, or the long and short forms of the prolactin receptor (PRLR) [137]. Furthermore, in mice, protein restriction of pregnant mothers resulted in lower levels of leptin mRNA and protein in the offspring [138]. In contrast, pups born to mothers submitted to a high-fat diet showed worse glucose tolerance and higher leptin levels and lower adiponectin levels in the adipose tissue than their control littermates, which was associated with higher H3K9Ac and lower $\mathrm{H} 3 \mathrm{~K} 9 \mathrm{me} 2$ levels at the adiponectin promoter and lower levels of H4K20me at the leptin promoter [139]. 


\section{CHROMATIN AS A NUTRIENT SENSOR: NUTRITION-INDUCED POST-}

TRANSLATIONAL MODIFICATIONS OF HISTONE PROTEINS AND THEIR EFFECTS ON CHROMATIN FUNCTION.

Nutrition has long been considered a major environmental factor responsible for changes in the transcriptome, mainly by the binding of small ligands to nuclear receptors, transcription factors, or cofactors [140]. Nevertheless, recent years have seen a number of reports in which small metabolites or nutrients controlled patterns of gene expression not by binding to single, specific targets but by modulating the global level of post-translational modifications (PTMs) of DNA, histones, and other epigenetic regulators (see [141] for a recent review). These "epigenetic metabolites" constitute a functional link between nutrition and regulation of gene expression, with poor nutrition and metabolite shortage affecting the appropriate deployment of epigenetic tags. This highlights chromatin architecture as a marker of the energetic and metabolic state of the cell. According to this model, chromatin would act as a metabolic sensor to adjust global patterns of gene expression to the dynamic changes in the concentration of specific metabolites, while ensuring its epigenetic inheritance [142]. This novel perception of metabolite-dependent chromatin function will surely provide researchers with conceptual tools to unravel the epigenetic components underlying reprogramming of gene expression by early-life nutritional stress, as well as to study the mechanisms that translate these regulatory alterations in risk increases to adult disease. In this section, we review the regulatory function of the best characterized of these epigenetic metabolites: O-linked-N-acetylglucosamine (O-GlcNAc), NAD+, and acetyl-CoA, as well as their functional relationship with chromatin and Sirtuin1, two of the better characterized metabolic sensors.

\subsection{Intracellular O-GIcNAcylation depends on the extracellular levels of glucose through the nutrient sensor UDP-GlcNAc}

Among the different intermediate metabolites with a confirmed role in the establishment or maintenance of histone PTMs, O-linked-N-acetylglucosamine constitutes a class of its own. Addition of an O-linked-N-acetylglucosamine group (OGlcNAc) to Ser/Thr residues of nuclear proteins [143] targets hundreds of proteins, among them epigenetic regulators and chromatin-associated proteins such as histones, members of the polycomb repressive complex, and a number of HDACs directly involved in the regulation of gene expression (see [144] for a recent review). 
GlcNAc is reversibly added to its target proteins as a single residue by the $\mathrm{O}$ is removed by the O-GlcNAcase (OGA) enzyme. Both reactions constitute the "OGlcNAc cycle". O-GlcNAc and O-GlcNAcylated products can be found not only in the nucleus or cytoplasm, but also in the endoplasmic reticulum-Golgi axis where they are used in the biosynthesis of glycoproteins, glycosaminoglycans, or glycolipids [145]. The precursor form UDP-GlcNAc, which is synthesized by the hexosamine biosynthetic pathway, can be considered a sensor of the metabolic state of the cell [146], since its synthesis requires four metabolites, glucose (carbohydrates), glutamine (aminoacids), acetyl CoA (lipids), UTP (nucleotides), and ATP as energy donor; their availability directly determines UDP-GlcNAclevels and subsequently those of intracellular OGlcNAcylation [146]. Thus, the levels of UDP-GlcNAc reflect the nutrient status of the cell, with extracellular levels of glucose modulating the extent of intracellular OGlcNAcylation [147]. Moreover, the O-GlcNAc cycle is functionally integrated with other nutrient sensing pathways such as mTOR, AMPK (which is activated by a low ATP/AMP ratio), MAPK, and insulin-AKT and the direct interaction of OGT with tyrosine kinase receptors, PIP3 sites, or p38 MAPK has been described, suggesting that these signaling pathways could also be modulated by O-GlcNAcylation (see Figure 3 and [148]).

\subsection{The activity of a number of epigenetic regulators of gene expression is controlled by $\mathbf{O}$-GlcNAcylation}

In a gene expression analysis in C. elegans, Love et al. found over 800 promoters modified by O-GlcNAcylation in which disruption of the O-GlcNAc cycle led to alterations in the pattern of gene expression, many of them linked to lipid/carbohydrate metabolism or microRNA expression; this constituted a nutrientresponsive program of gene expression [149]. In a mice model, male levels of OGT and of O-GlcNAc were seen to be reduced by early prenatal maternal stress, which affected hypothalamic gene expression as well as the landscape of brain microRNA expression [150].

On the other hand, Medford et al. demonstrated that the chronic ingestion of a sugar and saturated fat-rich diet (Western diet) increased protein O-GlcNAcylation in the hearts of rats, without modifying the levels of the OGT/OGA enzymes, which suggested that accumulation of O-GlcNAcylated products was due to the increased 
availability of nutrients [151]. This result has the utmost importance because it links the degree of protein O-GlcNAcylation to the historical record of nutrient ingestion. Among the proteins that were post-translationally modified by O-GlcNAcylation, the group of gene expression regulators is well represented. Several excellent reviews on the OGlcNAcylation of transcription factors have been recently published (see [152] and references therein); here we will focus on the epigenetic mechanisms affected by $\mathrm{O}$ GlcNAcylation.

On the functional side, O-GlcNAcylation has been shown to regulate chromatin dynamics through two different mechanisms: i- by tagging members of the polycomb group of proteins (PcG) [153] and other epigenetic regulators, such as the Ten-Eleven Translocation (TET) family of DNA hydroxylases/demethylases [154], and ii- by directly targeting the four core histones in chromatin $[155,156]$, although it seems that there is also some extent of crosstalk between the two mechanisms. The polycomb group proteins are transcriptional regulators that mediate the repression of numerous genes along the development to adulthood. Polycomb group proteins form two polycomb-repressive complexes (PRC1 and PRC2), which recognize and bind polycomb-responsive elements (PREs) at the regulatory regions of their target genes. PRC2s are H3K27 trimethyltransferases while PRC1 binds to H3K27me3 and monoubiquitinates H2AK119, with the overall effect of repressing the expression of the target genes [157].

In two thought-provoking studies, the polyhomeotic protein $(\mathrm{Ph})$, one of the components of PRC1, was shown to be O-GlcNAcylated [158], while the O-linked GlcNAc transferase (OGT) enzyme was identified as the PcG member previously known as super sex combs (sxc) [158, 159]; O-GlcNAcylation-defective null-mutants $\left(\mathrm{s} x c / O g t^{-1}\right)$ were unable to maintain polycomb-mediated transcriptional repression [158]. This last result strongly supports a role for the nutrient sensor O-GlcNAc in the repression of polycomb target genes and provides mechanistic insight on the functional relationship among nutrients and the transcriptional machinery. On the other hand, OGlcNAc sites have been detected in all the core histones, cross-talking with other histone PTMs. Thus H3S10GlcNAc impaired the phosphorylation of the same residue [155], H2BS112GlcNAc facilitated H2BK120 monoubiquitination [160], and H3T32GlcNAc reduced phosphorylation at H3S10, H3S28, and H3T32 [161]. 
The O-GlcNAcylation of target histones was facilitated by the binding of OGT start sites enriched in the activation mark $\mathrm{H} 3 \mathrm{~K} 4 \mathrm{me} 3$, while loss of OGT or TET $2 / 3$ reduced the target gene expression $[154,162]$. In this way, O-GlcNAcylation would have a dual role in the control of gene expression, reinforcing the repressive role of polycomb on its targets and facilitating transcription by binding to TET2/3 proteins. How these two opposite roles are regulated is currently unknown.

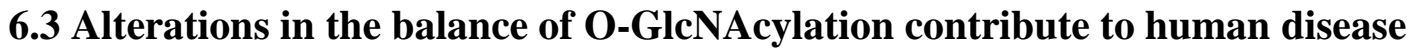

Recent years have seen evidences that an altered flow of O-GlcNAc could contribute to obesity, CVD, and T2D [163], to the extent that determination of OGlcNAc in blood has been proposed as a biomarker for early metabolic dysfunction in youngsters [164]. As stated above, levels of O-GlcNAc depend on the balance between the opposite activities of OGT (GlcNAcylation) and OGA (O-GlcNAc removal), and changes in their activity have been associated to human pathology, although the molecular mechanisms involved have not yet been clarified. The chemical inhibition of OGA resulted in increased levels of GlcNAc and impeded insulin-dependent phosphorylation of Akt and GSK3 $\beta$, leading to insulin resistance in 3T3-L1 adipocytes [165]. In contrast, heterozygous OGA-deficient mice had reduced insulin sensitivity, hyperleptinemia, and showed a de-regulated expression of genes associated with growth, innate immunity, and the metabolism of glucose, lipids, sterols, and calcium [166]. On the other hand, increasing GlcNAc levels by the transgenic overexpression of OGT induced insulin resistance and hyperleptinemia when OGT was expressed in muscle and adipose tissue [167], and was associated with obesity and fatty liver when it was expressed in liver, likely by interfering with the metabolism of Apo B and Apo A-I [168].

\subsection{Other metabolic sensors: SIRT1, Acetyl-CoA, and FAD}

In addition to O-GlcNAc, other metabolic sensors link DNA and chromatin PTMs (and hence regulated gene expression) to the levels of different metabolites in a way that could be epigenetically inherited, potentially contributing to the long-term effects of nutrition on adult disease risk. One of the best characterized is Sirtuin1 (SIRT1), a nuclear $\mathrm{NAD}^{+}$-dependent protein deacetylase which links cellular metabolic $\underline{\text { status (such as NAD }{ }^{+} \text {levels, modulated by dietary niacin) to the dynamics of chromatin }}$ architecture and regulated gene expression through the deacetylation of histones and 
other nuclear regulatory proteins [169]. In this sense, SIRT1 has been considered as a master regulator of the transcriptional networks that control lipid metabolism, gluconeogenesis, insulin secretion, and inflammation [170]. A recent analysis of the liver acetylome from Sirt1-deficient $\left(\operatorname{Sirt1}^{-1-}\right)$ mice allowed the detection and identification of a group of nuclear proteins directly deacetylated by SIRT1 "in vitro", among them a subunit of the SWI/SNF chromatin remodeling complex and five proteins involved in RNA processing [171]. Other chromatin-associated proteins have been characterized as substrates for the SIRT1 deacetylase activity, including the transcriptional repressor promyelocytic leukemia zinc finger protein (PLZF) [172], the histone methyltransferase mixed-lineage leukemia 1 (MLL1) associated to H3K4 trimethylation at certain promoters [173], and SATB1 homeobox 1, the regulator of high-order chromatin structure [174]. Also related to $\mathrm{NAD}^{+}$sensing, the globular macro domain constitutes a highly conserved protein fold present in histone variants (macroH2A), modifiers (macro-PARPs), and chromatin remodelers (Alc1) (see [175] for a recent review), which functions as an ADP-ribose binding module [176], likely mediating transcriptional regulation in response to nutrient availability.

On the other hand, acetyl-CoA is the acetyl donor for histone lysine acetylation by histone acetyl transferases (HATs). Independently of its role in the synthesis of OGlcNAc, acetyl-CoA has been considered a metabolic sensor by itself. Wellen et al. showed that suppression of the ATP-citrate lyase activity (the enzyme that converts glucose-derived citrate to acetyl-CoA) resulted in a global decline in histone acetylation, and more specifically in the hypoacetylation of the promoter region of the glucose transporter GLUT4 gene in adipocytes, thus linking glucose availability to the activation of a glucolytic program of gene expression [177]. Finally, other metabolites whose levels change in response to the nutrient status and are involved in the epigenetic regulation of gene expression have been described ([178], and references therein). These include FAD, a riboflavin (vitamin B12) derivative that works as a cofactor of LSD1, a H3K4 histone demethylase [179].

\subsection{Effect of plant bioactive compounds on epigenetic regulators}

In recent years, a number of dietary bioactive compounds of plant origin have been characterized as epigenetic modulators of gene expression because of their ability to reshape histone post-translational modification marks or DNA methylation patterns, although their exact role in maintaining the altered patterns required to establish lifelong 
effects remains poorly understood. In this section, we review recent reports on the direct the activity of enzymes directly involved in the structural/regulatory modifications of chromatin. We will not discuss the effects of caloric intake or of changes in micro/macronutrient consumption because there are excellent recent reviews on this topic [180].

Polyphenols such as curcumin, resveratrol, genistein, or ECGG constitute a complex class of plant secondary metabolites with an accepted role as epigenetic modulators. Curcumin (diferuloymethane) is a bioactive compound with anti-oxidative, anti-inflammatory, and anti-lipidemic properties and contributes to epigenetic regulation by downregulating expression of DNA methyltransferases (DNMT1, 3A and 3B) [181] and inhibiting HAT activity [182]. Furthermore, curcumin treatment was seen to alter expression of a large set of miRNAs, and consequently of their target genes [183], to upregulate the tumor suppressor lncRNA MEG3 [184], as well as to suppress expression from the H19 locus, but not from IGF2, in cancer cell lines [185]. $\underline{\text { Resveratrol is another phytochemical with an established role as epigenetic regulator. }}$ Resveratrol activates SIRT1 by increasing its binding to laminA [186] and inhibits mono-ubiquitination of histone $\mathrm{H} 2 \mathrm{~B}$ at K120 [187], which has an impact on the landscape of histone marks. Furthermore, resveratrol has been shown to regulate expression of the chromatin modifier metastasis-associated protein 1 (MTA1), a component of the silencing nucleosome remodeling and deacetylating complex (NuRD) [188]. On the other hand, the soybean isoflavone genistein has been observed to promote hypermethylation of $\mathrm{CpG}$ islands in specific mouse genes [189], as well as to modulate H3K19 methylation or deacetylation of specific promoters through a reduction of SIRT1 activity [190], while garcinol has been characterized as a potent inhibitor of histone acetyltransferases [191], cambinol as an inhibitor of SIRT1 and $\underline{\text { SIRT2 [192], and chaetocin as an inhibitor of histone } \mathrm{H} 3 \text { lysine } 9 \text { (H3K9), a }}$ methyltransferase suppressor of the variegation 3-9 homolog 1 (Suv39 h1) [193]

The list of phytochemicals with epigenetic regulatory potential is not restricted to polyphenols, but should also include sulforaphane (SFN), a dietary isothiocyanate, and allyl sulphides $[194,195]$, which function as HDAC inhibitors "in vitro", and green tea catechins, especially epigallocatechin gallate (EGCG), which have been shown to downmodulate DNA methylation by attenuating the effect of DNA methyltransferase 1 
(DNMT1) through a yet unknown mechanism, although various authors have shown the reexpression of tumor suppressors $\mathrm{p} 16^{\mathrm{INK} 4 \mathrm{a}}$ and $\mathrm{p} 15^{\mathrm{INK} 4 \mathrm{~b}}$ and WIF1 upon treatment of tumor cell lines with EGCG ([196] and references therein).

\section{XENOMIRS AND METASTABLE EPIALLELES: DOUBLE-EDGED SWORDS FOR NUTRIGENOMIC INTERVENTION.}

The safety of nutrigenomic intervention is widely accepted, mainly because the accidental ingestion of physiologically toxic amounts of polyphenols and other plant metabolites seems to be highly unlikely. Nevertheless, physiologically safe levels of ingested nutrients and metabolites could have undesired effects on epigenetic regulators [197, 198]. Of special concern are genes that harbor metastable epialleles (MEs), i.e. alleles which generate phenotypical variation through differential methylation, in their regulatory regions [199]. Metastable epialleles have been shown to promote the spreading of methylation to neighboring genes, thus contributing to their untimely epigenetic silencing [200]. What makes regulatory MEs interesting for nutraceutical research is the potential modulation of expression of their associated genes by environmental factors, with the degree of DNA methylation at their promoters reflecting the maternal intake of folic acid,as in the agouti and axin-fused genes [111, 116]. This environmental sensitivity makes ME-harboring genes likely targets for nutraceutical intervention, as well as interesting candidates to explain the long-term susceptibility to chronic diseases by linking prenatal exposures (e.g. to maternal folate) to the developmental plasticity of the epigenome [201]. In this context, Waterland et al. described a number of human MEs and studied their dynamics in a model of seasonal food shortage in Gambian subsistence farmers. They compared levels of methylation in MEs from individuals conceived in scarce vs. affluent conditions, and found them to be significantly increased in individuals conceived in the challenging season [202], probably due to seasonal variations in the intake of methyl donors by the pregnant mothers, although no data were provided on the expression variations of the MEassociated genes [203, 204]. To make things more interesting, a recent report showed that genomic regions flanking human MEs were enriched in repetitive sequences of the long interspersed nuclear element (LINE) or endogenous retrovirus (ERV) families [205], a relevant result because murine MEs have also been localized next to retroviruses and other transposable elements that generate epigenetic variability or 
instability [206, 207] or affect the transcriptional pattern of the locus [208]. Other authors have detected hypermethylated, leaky elements of the Alu [200] or B1 [209, 210] families that spread methylation to flanking regions and consequently contributed to the silencing of contiguous genes. Clearly, more research is needed on the function and dynamics of MEs, on their associated genes, and on their role as spreaders of methylation and gene-silencers; nonetheless, MEs could provide the degree of phenotypic variability needed to explain some of the long-term effects of early-life nutrition.

Another risky association between nutrition and the epigenetic machinery deals with the recently described xenomiRs or xenomiRNAs, i.e., exogenous plant or animalderived miRNAs [211]. In a highly controversial report, Zhang et al. described that the plant-specific microRNA miR-168a could be acquired by animals through food ingestion, survive the acidic conditions of stomach, target the low-density lipoprotein receptor adapter protein 1 (LDLRAP1) mRNA, and reduce the liver expression of LDLRAP1 protein [212]. Similarly, Baier et al. reported that miR-29b and miR-200c could be acquired by humans through milk consumption, and that miR-29b could target the runt-related transcription factor-2 (RUNX2) mRNA and miR-200c the ZEB1 mRNA in "in vitro" luciferase assays [213]. Furthermore, these authors showed that depletion of these miRNAs from milk was not compensated by intracellular synthesis, suggesting that humans relied on continuous exogenous supply of miR-29b and miR-200c [213]. Although these results have been openly questioned [214-217], with some laboratories being unable to replicate them [218] and others considering them as laboratory artifacts [219], the idea that xenomiRs could regulate the expression of target genes in humans or animals is fascinating (see [220] for a recent review), and could open a conceptual gate for the direct use of miRNA-characterized diets in nutritional interventions aimed to stop disease progression [221, 222]. It is likely that the coming years will see enormous progress in this highly controversial research area.

\section{CONCLUSIONSAND FUTURE TRENDS}

The epidemic of obesity that currently affects the western world has generated great interest in identifying the molecular mechanisms involved in the onset and progression of obesity and its related conditions. Of special interest are the effects of prenatal nutrition on the long-term risk of chronic diseases, as well as the genetic and 
epigenetic mechanisms that regulate the expression of genes critical for the appropriate work on the interface between nutrition and epigenetic mechanisms, i.e., how nutrients have an impact on the covalent marks of DNA and histones that have a direct role in the regulation of gene expression. Although this field of research is quite young, enough data are available to draw a number of conclusions that could serve as a theoretical basis for the development of further investigations: i.- early-life malnutrition results in increased risk of obesity and related conditions in adulthood, according to sound epidemiological evidence from studies in historical cohorts; ii.- nutrition has a direct impact on the expression of a number of responsive genes, and the availability of specific nutrients, such as methyl donors or folate, can modulate expression of certain genes (e.g., the Agouti gene) by changing the degree of methylation of their regulatory regions; iii-chromatin could be considered a metabolic/nutrient sensor that responds to nutritional cues by changing the patterns of gene expression. The post-translational addition of O-GclNAc, whose intracellular levels reflect the metabolic status of the cell, modulates gene expression by tagging histone proteins and members of the polycomb group of proteins $(\mathrm{PcG})$, among others. Thus poor nutrition, leading to a metabolite shortage, could affect the appropriate deployment of epigenetic tags and, subsequently, the growth and development of critical organs and tissues.

A general overview of this topic would highlight evidence that early environmental exposures (such as nutrition) can affect (i.e. reprogram) the developmental plasticity of key tissues and organs by affecting epigenetic mechanisms that control gene expression. Nevertheless, this explanation remains a theoretical structure because we still lack a mechanistic view of the processes involved. The many unknowns include the genes affected, the number and nature of their nutrient-sensitive regulatory regions, the epigenetic regulators involved, the gene-modulating role of specific nutrients and metabolites, aa well as the developmental alterations generated in the critical tissues and organs. On the other hand, the promising insights into the regulating roles of xenomiRNAs or of the metastable epialleles in nutrition-dependent changes make them worthy of study because of their ground-breaking potential as regulatory mechanisms, as well as their yet unforeseen physiological impacts.

These will definitely be future fields of active research because they correspond to the primary questions raised by the data here reviewed. Nevertheless, we would pose 
other, perhaps more philosophical, questions. It would be very important to describe the molecular mechanisms by which the cellular memory of the initial nutritional insult is established in early life and propagated to adulthood, i.e., to understand why the predisposition "awakens" 40-50 years later. We could hypothesize a requirement for a second signal, or the interaction of nutritionally primed epigenetic mediators with the aging machinery of the cell. In addition, it is tempting to speculate that nutrition-derived reductions in prenatal nutritional/metabolic sensors (such as the methyl donors or UDPGlcNAc,among others) could somehow affect the activity of critical, as yet unknown, regulatory regions or epigenetic regulators, leading to a gradual loss of epigenetic tags and/or other signals important for the maintenance of gene expression homeostasis. The affected cells would thus enter a state of gradual "regulatory exhaustion" that would hinder their physiological stability.

It is clear that a deep knowledge of the genetic and epigenetic mechanisms involved in nutrition-dependent reprogramming would likely provide us with tools for primary prevention as well as to reverse the process and, hopefully, its effects on longterm disease susceptibility. Of course, much more research is needed to fulfill this objective, and it is likely that the coming years will see a dramatic advance in research on the nutrition-dependent alterations in gene expression and the associated increases in disease risk. 


\section{ACKNOWLEDGMENTS}

The authors appreciate the English revision by Elaine Lilly, $\mathrm{PhD}$ (Writers First Aid). This research was supported by a grant (2FD097-0297-CO2-01) from Fondo Europeo de Desarrollo Regional (FEDER); by a scholarship for $\mathrm{PhD}$ training from a national program to prepare university professors (FPU), Ministry of Education of Spain (AP2010-3198); and also partially supported by FEDER [CB06/02/0029] and Red Investigación Cardiovascular, HERACLES [RD12/0042]), and AGAUR (2014 SGR 240) and (2014 SGR 0334). The CIBERESP and CIBEROBN are initiatives of the Instituto de Salud Carlos III, Madrid, Spain. We apologize to all our colleagues whose work has not been cited for reasons of space limitations.

\section{CONFLICTS OF INTEREST}

None

\section{ROLE OF THE FUNDING SOURCE}

The funding sources had no involvement in the collection, analysis, and interpretation of data; in the writing of the report; or in the decision to submit the article for publication 


\section{TABLE LEGENDS}

Table 1: Consequences of maternal malnutrition during the Dutch famine (19441945) on the development of chronic diseases at adulthood of their descendants

AGE : Age at which the analysis was performed in descendants of mothers exposed to famine.

(*) When the age of the subjects is not stated, the year at which the study was published is indicated

MATERNAL EXPOSURE TO HUNGER: gestation period in which mothers were exposed to famine

(**) Late gestation: babies born between 7 January1945 and 28 April 1945

Mid gestation: babies born between 29 April 1945 and 18 August 1945

Early gestation: babies born between 19 August 1945 and 8 December 1945

For the control groups not exposed to famine see each reference.

Table 2:Summary of selected histone post-translational modifications (acetylation or methylation) and their association to functional states of chromatin

Only individual labels are shown, not their combinations.

Bivalent domain: histone tag that represses developmentally expressed genes while maintaining them poised for activation upon differentiation.

TSS: Transcription Start Site

The code for histone labels is as follows: (H2B, 3, 4)-Histone 2B, 3 or 4, (K)-lysine, (ac)-acetylation, (me)-methylation. The number after the lysine code indicates the position modified, and me1, 2, 3 indicates mono- di- or tri methylations. This is a selection of significant histone labels and by no means an exhaustive inventory of all known histone post-translational modifications (PTMs). 


\section{FIGURE LEGENDS}

Figure 1: New families of RNAs which control the flow of genetic information, and their functional interactions

Boxes show components of the original "Central Dogma of Molecular Biology", which described the flow of genetic information from DNA to protein and considered mRNA essentially as an information-encoding, unstable intermediate [41, 42, 223]. This perspective has been updated by adding relevant families of non-coding RNAs, discovered recently, which are also transcribed from genomic DNA and have a functional role in the control of gene expression. These include the following: piRNAs, Piwi-interacting RNAs; sncRNAs, small non-coding RNAs; lncRNAs, long non-coding RNAs; and miRNAs, micro RNAs. Solid arrows indicate transcription, the dotted arrow stands for translation, and the dashed arrows represent a regulatory relationship between two species of nucleic acids.

These relationships are described as follows:

A- microRNAs that regulate stability or translability of mRNAs [61];

B- IncRNAs that regulate mRNA processing, stability and degradation [224];

C- IncRNAs that can function as "miRNA sponges" to reduce their effective concentration [225];

D- miRNAs that target and downregulate lncRNAs [226];

E- antisense, AS-lncRNAs that regulate expression of neighboring genes, lncRNAs (as XIST) involved in imprinting and silencing of gene expression, or enhancer RNAs (eRNAs) that activate gene expression [79, 227, 228], among others;

F- generation of new regulatory regions by retrotransposition near other functional genes [229];

G- small RNAs involved in retroelement silencing in the germline [230].

This figure reviews only some of the most relevant non-coding RNA families, and is neither a systematic catalog of these elements nor of their functions. We have focused on the functional interactions between coding and non-coding RNAs and with DNA, not considering their mutual impacts on proteins.

\section{Figure 2: Transcriptional regulation of the imprinted $\mathrm{IgF2} / \mathrm{H19}$ locus}

Shown are the $I g F 2$ and $H 19$ genes as well as the most relevant controlling elements which regulate their parentally specific expression: the differentially methylated region 
(DMR) and the distal 3' transcriptional enhancer. In this parentally imprinted locus the maternal chromosome keeps the DMR unmethylated so that it can bind the insulator zinc-finger protein $\mathrm{CTCF}$, which blocks the communication between the $I g F 2$ promoter and the distal enhancer [231], resulting in the transcriptional activation of the $H 19$ gene. On the other hand, CTCF fails to bind to the heavily methylated DMR from the paternal chromosome, which facilitates the interaction between the distal enhancer and the $I g F 2$ promoter to induce its expression.

\section{Figure 3: Chromatin as a nutrient sensor: GlcNAcylation of chromatin and} epigenetic regulators links the nutritional status of the cell with mechanisms regulating gene expression

Nutrient availability regulates levels of UDP-GlcNAc through the hexosamine biosynthetic pathway; this mechanism is controlled by a number of nutrient-sensing pathways (mTOR, AMPK, etc). GlcNAcylation of chromatin and other epigenetic regulators such as histones, polycomb group proteins (PcG), HDACs, TET (Ten-Eleven Translocation) proteins, and associated transcription factors (see text for details) have a global impact on the regulation of gene expression. 


\section{REFERENCES}

[1] Lee BC, Lee J. Cellular and molecular players in adipose tissue inflammation in the development of obesity-induced insulin resistance. Biochim Biophys Acta. 2014; 1842:446-62.

[2] Navarro E, Funtikova AN, Fito M, Schroder H. Can metabolically healthy obesity be explained by diet, genetics, and inflammation? Mol Nutr Food Res. 2015;59:75-93.

[3] Barker DJ. The fetal and infant origins of adult disease. Bmj. 1990;301:1111.

[4] Gut P, Verdin E. The nexus of chromatin regulation and intermediary metabolism. Nature. 2013;502:489-98.

[5] Kermack WO, McKendrick AG, McKinlay PL. Death-rates in Great Britain and Sweden: Expression of Specific Mortality Rates as Products of Two Factors, and some Consequences thereof. J Hyg (Lond). 1934;34:433-57.

[6] Forsdahl A. Are poor living conditions in childhood and adolescence an important risk factor for arteriosclerotic heart disease? Br J Prev Soc Med. 1977;31:91-5.

[7] Barker DJ, Osmond C. Infant mortality, childhood nutrition, and ischaemic heart disease in England and Wales. Lancet. 1986;1:1077-81.

[8] Barker DJ, Winter PD, Osmond C, Margetts B, Simmonds SJ. Weight in infancy and death from ischaemic heart disease. Lancet. 1989;2:577-80.

[9] Hales CN, Barker DJ, Clark PM, Cox LJ, Fall C, Osmond C, et al. Fetal and infant growth and impaired glucose tolerance at age 64. Bmj. 1991;303:1019-22.

[10] Hales CN, Barker DJ. Type 2 (non-insulin-dependent) diabetes mellitus: the thrifty phenotype hypothesis. 1992. Int J Epidemiol. 1992;42:1215-22.

[11] Vickers MH, Breier BH, Cutfield WS, Hofman PL, Gluckman PD. Fetal origins of hyperphagia, obesity, and hypertension and postnatal amplification by hypercaloric nutrition. Am J Physiol Endocrinol Metab. 2000;279:E83-7.

[12] Bateson P, Barker D, Clutton-Brock T, Deb D, D'Udine B, Foley RA, et al. Developmental plasticity and human health. Nature. 2004;430:419-21.

[13] Calkins K, Devaskar SU. Fetal origins of adult disease. Curr Probl Pediatr Adolesc Health Care. 2011;41:158-76.

[14] Hales CN, Barker DJ. The thrifty phenotype hypothesis. Br Med Bull. 2001;60:520.

[15] Langley-Evans SC. Nutritional programming of disease: unravelling the mechanism. J Anat. 2009;215:36-51.

[16] Ojha S, Saroha V, Symonds ME, Budge H. Excess nutrient supply in early life and its later metabolic consequences. Clin Exp Pharmacol Physiol. 2013;40:817-23.

[17] Singhal A, Lucas A. Early origins of cardiovascular disease: is there a unifying hypothesis? Lancet. 2004;363:1642-5.

[18] Singhal A, Kennedy K, Lanigan J, Fewtrell M, Cole TJ, Stephenson T, et al. Nutrition in infancy and long-term risk of obesity: evidence from 2 randomized controlled trials. Am J Clin Nutr. 2010;92:1133-44.

[19] Wells JC. Historical cohort studies and the early origins of disease hypothesis: making sense of the evidence. Proc Nutr Soc. 2009;68:179-88.

[20] Ravelli GP, Stein ZA, Susser MW. Obesity in young men after famine exposure in utero and early infancy. N Engl J Med. 1976;295:349-53.

[21] Painter RC, Roseboom TJ, Bleker OP. Prenatal exposure to the Dutch famine and disease in later life: an overview. Reprod Toxicol. 2005;20:345-52. 
[22] Ravelli AC, van der Meulen JH, Michels RP, Osmond C, Barker DJ, Hales CN, et al. Glucose tolerance in adults after prenatal exposure to famine. Lancet. 1998;351:1737.

[23] Ravelli AC, van Der Meulen JH, Osmond C, Barker DJ, Bleker OP. Obesity at the age of $50 \mathrm{y}$ in men and women exposed to famine prenatally. Am J Clin Nutr. 1999;70:811-6.

[24] Roseboom T, de Rooij S, Painter R. The Dutch famine and its long-term consequences for adult health. Early Hum Dev. 2006;82:485-91.

[25] Veenendaal MV, Painter RC, de Rooij SR, Bossuyt PM, van der Post JA, Gluckman PD, et al. Transgenerational effects of prenatal exposure to the 1944-45 Dutch famine. Bjog. 2013;120:548-53.

[26] van Abeelen AF, Elias SG, Bossuyt PM, Grobbee DE, van der Schouw YT, Roseboom TJ, et al. Famine exposure in the young and the risk of type 2 diabetes in adulthood. Diabetes. 2012;61:2255-60.

[27] van Abeelen AF, Veenendaal MV, Painter RC, de Rooij SR, Dijkgraaf MG, Bossuyt PM, et al. Survival effects of prenatal famine exposure. Am J Clin Nutr. 2012;95:179-83.

[28] Painter RC, de Rooij SR, Bossuyt PM, Simmers TA, Osmond C, Barker DJ, et al. Early onset of coronary artery disease after prenatal exposure to the Dutch famine. Am J Clin Nutr. 2006;84:322-7; quiz 466-7.

[29] van Abeelen AF, Elias SG, Bossuyt PM, Grobbee DE, van der Schouw YT, Roseboom TJ, et al. Cardiovascular consequences of famine in the young. Eur Heart J. 2012;33:538-45.

[30] Lumey LH, Martini LH, Myerson M, Stein AD, Prineas RJ. No relation between coronary artery disease or electrocardiographic markers of disease in middle age and prenatal exposure to the Dutch famine of 1944-5. Heart. 2012;98:1653-9.

[31] Huxley RR, Neil HA. Does maternal nutrition in pregnancy and birth weight influence levels of CHD risk factors in adult life? Br J Nutr. 2004;91:459-68.

[32] Stanner SA, Bulmer K, Andres C, Lantseva OE, Borodina V, Poteen VV, et al. Does malnutrition in utero determine diabetes and coronary heart disease in adulthood? Results from the Leningrad siege study, a cross sectional study. Bmj. 1997;315:1342-8.

[33] Stanner SA, Yudkin JS. Fetal programming and the Leningrad Siege study. Twin Res. 2001;4:287-92.

[34] Rotar O, Moguchaia E, Boyarinova M, Kolesova E, Khromova N, Freylikhman O, et al. Seventy years after the siege of Leningrad: does early life famine still affect cardiovascular risk and aging? J Hypertens. 2015;33:1772-9; discussion 9.

[35] Yudkin JS, Stanner S. Prenatal exposure to famine and health in later life. Lancet. 1998;351:1361-2.

[36] Ruemmele FM, Garnier-Lengline H. Why are genetics important for nutrition? Lessons from epigenetic research. Ann Nutr Metab. 2012;60 Suppl 3:38-43.

[37] Pembrey M, Saffery R, Bygren LO. Human transgenerational responses to earlylife experience: potential impact on development, health and biomedical research. $\mathrm{J}$ Med Genet. 2014;51:563-72.

[38] Kaati G, Bygren LO, Edvinsson S. Cardiovascular and diabetes mortality determined by nutrition during parents' and grandparents' slow growth period. Eur J Hum Genet. 2002;10:682-8.

[39] Bygren LO, Tinghog P, Carstensen J, Edvinsson S, Kaati G, Pembrey ME, et al. Change in paternal grandmothers' early food supply influenced cardiovascular mortality of the female grandchildren. BMC Genet. 2014;15:12. 
[40] Painter RC, Osmond C, Gluckman P, Hanson M, Phillips DI, Roseboom TJ.

[41] Crick FH. On protein synthesis. Symp Soc Exp Biol. 1958;12:138-63.

[42] Brenner S, Jacob F, Meselson M. An unstable intermediate carrying information from genes to ribosomes for protein synthesis. Nature. 1961;190:576-81.

[43] Lander ES, Linton LM, Birren B, Nusbaum C, Zody MC, Baldwin J, et al. Initial sequencing and analysis of the human genome. Nature. 2001;409:860-921.

[44] Venter JC, Adams MD, Myers EW, Li PW, Mural RJ, Sutton GG, et al. The sequence of the human genome. Science. 2001;291:1304-51.

[45] International. Finishing the euchromatic sequence of the human genome. Nature. 2004;431:931-45.

[46] Pertea M, Salzberg SL. Between a chicken and a grape: estimating the number of human genes. Genome Biol. 2010;11:206.

[47] Shabalina SA, Spiridonov NA. The mammalian transcriptome and the function of non-coding DNA sequences. Genome Biol. 2004;5:105.

[48] Adams MD, Kerlavage AR, Fleischmann RD, Fuldner RA, Bult CJ, Lee NH, et al. Initial assessment of human gene diversity and expression patterns based upon 83 million nucleotides of cDNA sequence. Nature. 1995;377:3-174.

[49] Korenberg JR, Chen XN, Adams MD, Venter JC. Toward a cDNA map of the human genome. Genomics. 1995;29:364-70.

[50] Liang F, Holt I, Pertea G, Karamycheva S, Salzberg SL, Quackenbush J. Gene index analysis of the human genome estimates approximately 120,000 genes. Nat Genet. 2000;25:239-40.

[51] Carninci P, Waki K, Shiraki T, Konno H, Shibata K, Itoh M, et al. Targeting a complex transcriptome: the construction of the mouse full-length cDNA encyclopedia. Genome Res. 2003;13:1273-89.

[52] Carninci P. RNA dust: where are the genes? DNA Res. 2010;17:51-9.

[53] Costa FF. Non-coding RNAs: Meet thy masters. Bioessays. 2010;32:599-608.

[54] Wright MW, Bruford EA. Naming 'junk': human non-protein coding RNA (ncRNA) gene nomenclature. Hum Genomics. 2011;5:90-8.

[55] Consortium TEP. An integrated encyclopedia of DNA elements in the human genome. Nature. 2012;489:57-74.

[56] Thurman RE, Rynes E, Humbert R, Vierstra J, Maurano MT, Haugen E, et al. The accessible chromatin landscape of the human genome. Nature. 2012;489:75-82.

[57] Neph S, Vierstra J, Stergachis AB, Reynolds AP, Haugen E, Vernot B, et al. An expansive human regulatory lexicon encoded in transcription factor footprints. Nature. 2012;489:83-90.

[58] Gerstein MB, Kundaje A, Hariharan M, Landt SG, Yan KK, Cheng C, et al. Architecture of the human regulatory network derived from ENCODE data. Nature. 2012;489:91-100.

[59] Birney E, Stamatoyannopoulos JA, Dutta A, Guigo R, Gingeras TR, Margulies EH, et al. Identification and analysis of functional elements in $1 \%$ of the human genome by the ENCODE pilot project. Nature. 2007;447:799-816.

[60] Carninci P, Yasuda J, Hayashizaki Y. Multifaceted mammalian transcriptome. Curr Opin Cell Biol. 2008;20:274-80.

[61] Carthew RW, Sontheimer EJ. Origins and Mechanisms of miRNAs and siRNAs. Cell. 2009;136:642-55. 
[62] Kozomara A, Griffiths-Jones S. miRBase: annotating high confidence microRNAs using deep sequencing data. Nucleic Acids Res. 2014;42:D68-73.

[63] Vidigal JA, Ventura A. The biological functions of miRNAs: lessons from in vivo studies. Trends Cell Biol. 2015;25:137-47.

[64] Saki N, Abroun S, Soleimani M, Hajizamani S, Shahjahani M, Kast RE, et al. Involvement of MicroRNA in T-Cell Differentiation and Malignancy. Int J Hematol Oncol Stem Cell Res. 2015;9:33-49.

[65] Hata A, Lieberman J. Dysregulation of microRNA biogenesis and gene silencing in cancer. Sci Signal. 2015;8:re3.

[66] Andreou I, Sun X, Stone PH, Edelman ER, Feinberg MW. miRNAs in atherosclerotic plaque initiation, progression, and rupture. Trends Mol Med. 2015.

[67] Schulte C, Zeller T. microRNA-based diagnostics and therapy in cardiovascular disease-Summing up the facts. Cardiovasc Diagn Ther. 2015;5:17-36.

[68] Descalzi G, Ikegami D, Ushijima T, Nestler EJ, Zachariou V, Narita M. Epigenetic mechanisms of chronic pain. Trends Neurosci. 2015.

[69] Chung AC, Lan HY. MicroRNAs in renal fibrosis. Front Physiol. 2015;6:50.

[70] MacLellan SA, MacAulay C, Lam S, Garnis C. Pre-profiling factors influencing serum microRNA levels. BMC Clin Pathol. 2014;14:27.

[71] Papadopoulos T, Belliere J, Bascands JL, Neau E, Klein J, Schanstra JP. miRNAs in urine: a mirror image of kidney disease? Expert Rev Mol Diagn. 2015;15:361-74.

[72] Chevillet JR, Kang Q, Ruf IK, Briggs HA, Vojtech LN, Hughes SM, et al. Quantitative and stoichiometric analysis of the microRNA content of exosomes. Proc Natl Acad Sci U S A. 2015;111:14888-93.

[73] Simonson B, Das S. MicroRNA Therapeutics: the next magic bullet? Mini Rev Med Chem. 2015.

[74] Grote P, Herrmann BG. Long noncoding RNAs in organogenesis: making the difference. Trends Genet. 2015.

[75] Isin M, Dalay N. LncRNAs and neoplasia. Clin Chim Acta. 2015;444:280-8.

[76] Haemmerle M, Gutschner T. Long non-coding RNAs in cancer and development: where do we go from here? Int J Mol Sci. 2015;16:1395-405.

[77] Xie C, Yuan J, Li H, Li M, Zhao G, Bu D, et al. NONCODEv4: exploring the world of long non-coding RNA genes. Nucleic Acids Res. 2013;42:D98-103.

[78] Magistri M, Faghihi MA, St Laurent G, 3rd, Wahlestedt C. Regulation of chromatin structure by long noncoding RNAs: focus on natural antisense transcripts. Trends Genet. 2012;28:389-96.

[79] Jiao AL, Slack FJ. RNA-mediated gene activation. Epigenetics. 2014;9:27-36.

[80] Lam MT, Li W, Rosenfeld MG, Glass CK. Enhancer RNAs and regulated transcriptional programs. Trends Biochem Sci. 2014;39:170-82.

[81] Shibayama Y, Fanucchi S, Magagula L, Mhlanga MM. lncRNA and gene looping. Transcription. 2014;5:e28658.

[82] Jin B, Li Y, Robertson KD. DNA methylation: superior or subordinate in the epigenetic hierarchy? Genes Cancer. 2011;2:607-17.

[83] Portela A, Esteller M. Epigenetic modifications and human disease. Nat Biotechnol. 2010;28:1057-68.

[84] Bartholomew B. Regulating the chromatin landscape: structural and mechanistic perspectives. Annu Rev Biochem. 2014;83:671-96.

[85] Gurard-Levin ZA, Almouzni G. Histone modifications and a choice of variant: a language that helps the genome express itself. F1000Prime Rep. 2014;6:76. 
[86] Barth TK, Imhof A. Fast signals and slow marks: the dynamics of histone modifications. Trends Biochem Sci. 2010;35:618-26.

[87] Rothbart SB, Strahl BD. Interpreting the language of histone and DNA modifications. Biochim Biophys Acta. 2014;1839:627-43.

[88] Sadakierska-Chudy A, Kostrzewa RM, Filip M. A comprehensive view of the epigenetic landscape part I: DNA methylation, passive and active DNA demethylation pathways and histone variants. Neurotox Res. 2015;27:84-97.

[89] Zhang G, Pradhan S. Mammalian epigenetic mechanisms. IUBMB Life. 2014;66:240-56.

[90] Yost JM, Korboukh I, Liu F, Gao C, Jin J. Targets in epigenetics: inhibiting the methyl writers of the histone code. Curr Chem Genomics. 2011;5:72-84.

[91] Gillette TG, Hill JA. Readers, writers, and erasers: chromatin as the whiteboard of heart disease. Circ Res. 2015;116:1245-53.

[92] Patel DJ, Wang Z. Readout of epigenetic modifications. Annu Rev Biochem. 2014;82:81-118.

[93] Miltenberger RJ, Mynatt RL, Wilkinson JE, Woychik RP. The role of the agouti gene in the yellow obese syndrome. J Nutr. 1997;127:1902S-7S.

[94] Duhl DM, Vrieling H, Miller KA, Wolff GL, Barsh GS. Neomorphic agouti mutations in obese yellow mice. Nat Genet. 1994;8:59-65.

[95] Argeson AC, Nelson KK, Siracusa LD. Molecular basis of the pleiotropic phenotype of mice carrying the hypervariable yellow (Ahvy) mutation at the agouti locus. Genetics. 1996;142:557-67.

[96] Morgan HD, Sutherland HG, Martin DI, Whitelaw E. Epigenetic inheritance at the agouti locus in the mouse. Nat Genet. 1999;23:314-8.

[97] Waterland RA, Travisano M, Tahiliani KG. Diet-induced hypermethylation at agouti viable yellow is not inherited transgenerationally through the female. Faseb J. 2007;21:3380-5.

[98] Vasicek TJ, Zeng L, Guan XJ, Zhang T, Costantini F, Tilghman SM. Two dominant mutations in the mouse fused gene are the result of transposon insertions. Genetics. 1997;147:777-86.

[99] Zeng L, Fagotto F, Zhang T, Hsu W, Vasicek TJ, Perry WL, 3rd, et al. The mouse Fused locus encodes Axin, an inhibitor of the Wnt signaling pathway that regulates embryonic axis formation. Cell. 1997;90:181-92.

[100] Rakyan VK, Chong S, Champ ME, Cuthbert PC, Morgan HD, Luu KV, et al. Transgenerational inheritance of epigenetic states at the murine Axin(Fu) allele occurs after maternal and paternal transmission. Proc Natl Acad Sci U S A. 2003;100:2538-43. [101] Nordin M, Bergman D, Halje M, Engstrom W, Ward A. Epigenetic regulation of the Igf2/H19 gene cluster. Cell Prolif. 2014;47:189-99.

[102] Ludwig T, Eggenschwiler J, Fisher P, D'Ercole AJ, Davenport ML, Efstratiadis A. Mouse mutants lacking the type 2 IGF receptor (IGF2R) are rescued from perinatal lethality in Igf2 and Igf1r null backgrounds. Dev Biol. 1996;177:517-35.

[103] Keniry A, Oxley D, Monnier P, Kyba M, Dandolo L, Smits G, et al. The H19 lincRNA is a developmental reservoir of miR-675 that suppresses growth and Igf1r. Nat Cell Biol. 2012;14:659-65.

[104] Kato Y, Sasaki H. Imprinting and looping: epigenetic marks control interactions between regulatory elements. Bioessays. 2005;27:1-4.

[105] Ratajczak MZ. Igf2-H19, an Imprinted Tandem Yin-Yanggene and its Emerging Role in Development, Proliferation of Pluripotent Stem Cells, Senescence and Cancerogenesis. J Stem Cell Res Ther. 2012;2. 
[106] Anderson OS, Sant KE, Dolinoy DC. Nutrition and epigenetics: an interplay of dietary methyl donors, one-carbon metabolism and DNA methylation. J Nutr Biochem. 2012;23:853-9.

[107] McKay JA, Mathers JC. Diet induced epigenetic changes and their implications for health. Acta Physiol (Oxf). 2011;202:103-18.

[108] Mathias PC, Elmhiri G, de Oliveira JC, Delayre-Orthez C, Barella LF, Tofolo LP, et al. Maternal diet, bioactive molecules, and exercising as reprogramming tools of metabolic programming. Eur J Nutr. 2014;53:711-22.

[109] Wolff GL, Kodell RL, Moore SR, Cooney CA. Maternal epigenetics and methyl supplements affect agouti gene expression in Avy/a mice. Faseb J. 1998;12:949-57.

[110] Dolinoy DC, Weidman JR, Waterland RA, Jirtle RL. Maternal genistein alters coat color and protects Avy mouse offspring from obesity by modifying the fetal epigenome. Environ Health Perspect. 2006;114:567-72.

[111] Waterland RA, Jirtle RL. Transposable elements: targets for early nutritional effects on epigenetic gene regulation. Mol Cell Biol. 2003;23:5293-300.

[112] Bultman SJ, Michaud EJ, Woychik RP. Molecular characterization of the mouse agouti locus. Cell. 1992;71:1195-204.

[113] Klebig ML, Wilkinson JE, Geisler JG, Woychik RP. Ectopic expression of the agouti gene in transgenic mice causes obesity, features of type II diabetes, and yellow fur. Proc Natl Acad Sci U S A. 1995;92:4728-32.

[114] Mynatt RL, Stephens JM. Agouti regulates adipocyte transcription factors. Am J Physiol Cell Physiol. 2001;280:C954-61.

[115] Waterland RA, Travisano M, Tahiliani KG, Rached MT, Mirza S. Methyl donor supplementation prevents transgenerational amplification of obesity. Int J Obes (Lond). 2008;32:1373-9.

[116] Waterland RA, Dolinoy DC, Lin JR, Smith CA, Shi X, Tahiliani KG. Maternal methyl supplements increase offspring DNA methylation at Axin Fused. Genesis. 2006;44:401-6.

[117] Cropley JE, Suter CM, Beckman KB, Martin DI. CpG methylation of a silent controlling element in the murine Avy allele is incomplete and unresponsive to methyl donor supplementation. PLoS One. 2010;5:e9055.

[118] Dolinoy DC, Weinhouse C, Jones TR, Rozek LS, Jirtle RL. Variable histone modifications at the A(vy) metastable epiallele. Epigenetics. 2010;5:637-44.

[119] Heijmans BT, Tobi EW, Stein AD, Putter H, Blauw GJ, Susser ES, et al. Persistent epigenetic differences associated with prenatal exposure to famine in humans. Proc Natl Acad Sci U S A. 2008;105:17046-9.

[120] Bouwland-Both MI, van Mil NH, Stolk L, Eilers PH, Verbiest MM, Heijmans BT, et al. DNA methylation of IGF2DMR and H19 is associated with fetal and infant growth: the generation R study. PLoS One. 2013;8:e81731.

[121] Steegers-Theunissen RP, Obermann-Borst SA, Kremer D, Lindemans J, Siebel C, Steegers EA, et al. Periconceptional maternal folic acid use of 400 microg per day is related to increased methylation of the IGF2 gene in the very young child. PLoS One. 2009;4:e7845.

[122] Tobi EW, Lumey LH, Talens RP, Kremer D, Putter H, Stein AD, et al. DNA methylation differences after exposure to prenatal famine are common and timing- and sex-specific. Hum Mol Genet. 2009;18:4046-53.

[123] Tobi EW, Goeman JJ, Monajemi R, Gu H, Putter H, Zhang Y, et al. DNA methylation signatures link prenatal famine exposure to growth and metabolism. Nat Commun. 2014;5:5592. 
[124] Veenendaal MV, Costello PM, Lillycrop KA, de Rooij SR, van der Post JA, Bossuyt PM, et al. Prenatal famine exposure, health in later life and promoter methylation of four candidate genes. J Dev Orig Health Dis. 2012;3:450-7.

[125] Fujimoto K, Polonsky KS. Pdx1 and other factors that regulate pancreatic betacell survival. Diabetes Obes Metab. 2009;11 Suppl 4:30-7.

[126] Park JH, Stoffers DA, Nicholls RD, Simmons RA. Development of type 2 diabetes following intrauterine growth retardation in rats is associated with progressive epigenetic silencing of Pdx1. J Clin Invest. 2008;118:2316-24.

[127] Abuzgaia AM, Hardy DB, Arany E. Regulation of postnatal pancreatic Pdx1 and downstream target genes after gestational exposure to protein restriction in rats. Reproduction. 2015;149:293-303.

[128] Thompson RF, Fazzari MJ, Niu H, Barzilai N, Simmons RA, Greally JM. Experimental intrauterine growth restriction induces alterations in DNA methylation and gene expression in pancreatic islets of rats. J Biol Chem. 2010;285:15111-8.

[129] Zheng J, Xiao X, Zhang Q, Yu M, Xu J, Wang Z. Maternal protein restriction induces early-onset glucose intolerance and alters hepatic genes expression in the peroxisome proliferator-activated receptor pathway in offspring. J Diabetes Investig. 2014;6:269-79.

[130] Zheng S, Pan YX. Histone modifications, not DNA methylation, cause transcriptional repression of p16 (CDKN2A) in the mammary glands of offspring of protein-restricted rats. J Nutr Biochem. 2011;22:567-73.

[131] Zheng S, Rollet M, Yang K, Pan YX. A gestational low-protein diet represses p21(WAF1/Cip1) expression in the mammary gland of offspring rats through promoter histone modifications. Br J Nutr. 2012;108:998-1007.

[132] Sandovici I, Smith NH, Nitert MD, Ackers-Johnson M, Uribe-Lewis S, Ito Y, et al. Maternal diet and aging alter the epigenetic control of a promoter-enhancer interaction at the Hnf4a gene in rat pancreatic islets. Proc Natl Acad Sci U S A. 2011;108:5449-54.

[133] Wronska A, Kmiec Z. Structural and biochemical characteristics of various white adipose tissue depots. Acta Physiol (Oxf). 2015;205:194-208.

[134] Hilton C, Karpe F, Pinnick KE. Role of developmental transcription factors in white, brown and beige adipose tissues. Biochim Biophys Acta. 2015;1851:686-96.

[135] Oger F, Dubois-Chevalier J, Gheeraert C, Avner S, Durand E, Froguel P, et al. Peroxisome proliferator-activated receptor gamma regulates genes involved in insulin/insulin-like growth factor signaling and lipid metabolism during adipogenesis through functionally distinct enhancer classes. J Biol Chem. 2014;289:708-22.

[136] Lomax MA, Sadiq F, Karamanlidis G, Karamitri A, Trayhurn P, Hazlerigg DG. Ontogenic loss of brown adipose tissue sensitivity to beta-adrenergic stimulation in the ovine. Endocrinology. 2007;148:461-8.

[137] Bispham J, Gardner DS, Gnanalingham MG, Stephenson T, Symonds ME, Budge H. Maternal nutritional programming of fetal adipose tissue development: differential effects on messenger ribonucleic acid abundance for uncoupling proteins and peroxisome proliferator-activated and prolactin receptors. Endocrinology. 2005;146:3943-9.

[138] Jousse C, Parry L, Lambert-Langlais S, Maurin AC, Averous J, Bruhat A, et al. Perinatal undernutrition affects the methylation and expression of the leptin gene in adults: implication for the understanding of metabolic syndrome. Faseb J. 2011;25:3271-8. 
[139] Masuyama H, Hiramatsu Y. Effects of a high-fat diet exposure in utero on the metabolic syndrome-like phenomenon in mouse offspring through epigenetic changes in adipocytokine gene expression. Endocrinology. 2012;153:2823-30.

[140] Romagnolo DF, Zempleni J, Selmin OI. Nuclear receptors and epigenetic regulation: opportunities for nutritional targeting and disease prevention. Adv Nutr. 2014;5:373-85.

[141] Keating ST, El-Osta A. Epigenetics and metabolism. Circ Res. 2015;116:715-36.

[142] Katada S, Imhof A, Sassone-Corsi P. Connecting threads: epigenetics and metabolism. Cell. 2012;148:24-8.

[143] Sakabe K, Wang Z, Hart GW. Beta-N-acetylglucosamine (O-GlcNAc) is part of the histone code. Proc Natl Acad Sci U S A. 2010;107:19915-20.

[144] Hanover JA, Krause MW, Love DC. Bittersweet memories: linking metabolism to epigenetics through O-GlcNAcylation. Nat Rev Mol Cell Biol. 2012;13:312-21.

[145] Love DC, Krause MW, Hanover JA. O-GlcNAc cycling: emerging roles in development and epigenetics. Semin Cell Dev Biol. 2010;21:646-54.

[146] Zachara NE, Hart GW. O-GlcNAc a sensor of cellular state: the role of nucleocytoplasmic glycosylation in modulating cellular function in response to nutrition and stress. Biochim Biophys Acta. 2004;1673:13-28.

[147] Walgren JL, Vincent TS, Schey KL, Buse MG. High glucose and insulin promote O-GlcNAc modification of proteins, including alpha-tubulin. Am J Physiol Endocrinol Metab. 2003;284:E424-34.

[148] Hanover JA, Krause MW, Love DC. The hexosamine signaling pathway: OGlcNAc cycling in feast or famine. Biochim Biophys Acta. 2010;1800:80-95.

[149] Love DC, Ghosh S, Mondoux MA, Fukushige T, Wang P, Wilson MA, et al. Dynamic O-GlcNAc cycling at promoters of Caenorhabditis elegans genes regulating longevity, stress, and immunity. Proc Natl Acad Sci U S A. 2010;107:7413-8.

[150] Howerton CL, Morgan CP, Fischer DB, Bale TL. O-GlcNAc transferase (OGT) as a placental biomarker of maternal stress and reprogramming of CNS gene transcription in development. Proc Natl Acad Sci U S A. 2013;110:5169-74.

[151] Medford HM, Chatham JC, Marsh SA. Chronic ingestion of a Western diet increases O-linked-beta-N-acetylglucosamine (O-GlcNAc) protein modification in the rat heart. Life Sci. 2012;90:883-8.

[152] Gambetta MC, Muller J. A critical perspective of the diverse roles of O-GlcNAc transferase in chromatin. Chromosoma. 2015.

[153] Dehennaut V, Leprince D, Lefebvre T. O-GlcNAcylation, an Epigenetic Mark. Focus on the Histone Code, TET Family Proteins, and Polycomb Group Proteins. Front Endocrinol (Lausanne). 2014;5:155.

[154] Chen Q, Chen Y, Bian C, Fujiki R, Yu X. TET2 promotes histone OGlcNAcylation during gene transcription. Nature. 2013;493:561-4.

[155] Zhang S, Roche K, Nasheuer HP, Lowndes NF. Modification of histones by sugar beta-N-acetylglucosamine (GlcNAc) occurs on multiple residues, including histone $\mathrm{H} 3$ serine 10, and is cell cycle-regulated. J Biol Chem. 2011;286:37483-95.

[156] Ahmad W, Shabbiri K, Nazar N, Nazar S, Qaiser S, Shabbir Mughal MA. Human linker histones: interplay between phosphorylation and O-beta-GlcNAc to mediate chromatin structural modifications. Cell Div. 2011;6:15.

[157] Kerppola TK. Polycomb group complexes--many combinations, many functions. Trends Cell Biol. 2009;19:692-704.

[158] Gambetta MC, Oktaba K, Muller J. Essential role of the glycosyltransferase sxc/Ogt in polycomb repression. Science. 2009;325:93-6. 
[159] Sinclair DA, Syrzycka M, Macauley MS, Rastgardani T, Komljenovic I, Vocadlo DJ, et al. Drosophila O-GlcNAc transferase (OGT) is encoded by the Polycomb group (PcG) gene, super sex combs (sxc). Proc Natl Acad Sci U S A. 2009;106:13427-32.

[160] Fujiki R, Hashiba W, Sekine H, Yokoyama A, Chikanishi T, Ito S, et al. GlcNAcylation of histone $\mathrm{H} 2 \mathrm{~B}$ facilitates its monoubiquitination. Nature. 2011;480:557-60.

[161] Fong JJ, Nguyen BL, Bridger R, Medrano EE, Wells L, Pan S, et al. beta-NAcetylglucosamine (O-GlcNAc) is a novel regulator of mitosis-specific phosphorylations on histone H3. J Biol Chem. 2012;287:12195-203.

[162] Deplus R, Delatte B, Schwinn MK, Defrance M, Mendez J, Murphy N, et al. TET2 and TET3 regulate GlcNAcylation and H3K4 methylation through OGT and SET1/COMPASS. Embo J. 2013;32:645-55.

[163] Lefebvre T, Dehennaut V, Guinez C, Olivier S, Drougat L, Mir AM, et al. Dysregulation of the nutrient/stress sensor O-GlcNAcylation is involved in the etiology of cardiovascular disorders, type-2 diabetes and Alzheimer's disease. Biochim Biophys Acta. 2013;1800:67-79.

[164] Myslicki JP, Shearer J, Hittel DS, Hughey CC, Belke DD. O-GlcNAc modification is associated with insulin sensitivity in the whole blood of healthy young adult males. Diabetol Metab Syndr. 2014;6:96.

[165] Vosseller K, Wells L, Lane MD, Hart GW. Elevated nucleocytoplasmic glycosylation by O-GlcNAc results in insulin resistance associated with defects in Akt activation in 3T3-L1 adipocytes. Proc Natl Acad Sci U S A. 2002;99:5313-8.

[166] Keembiyehetty C, Love DC, Harwood KR, Gavrilova O, Comly ME, Hanover JA. Conditional knock-out reveals a requirement for O-linked N-Acetylglucosaminase (O-GlcNAcase) in metabolic homeostasis. J Biol Chem. 2015;290:7097-113.

[167] McClain DA, Lubas WA, Cooksey RC, Hazel M, Parker GJ, Love DC, et al. Altered glycan-dependent signaling induces insulin resistance and hyperleptinemia. Proc Natl Acad Sci U S A. 2002;99:10695-9.

[168] Lee J, Song EY, Chung TW, Kang SK, Kim KS, Chung TH, et al. Hyperexpression of $\mathrm{N}$-acetylglucosaminyltransferase-III in liver tissues of transgenic mice causes fatty body and obesity through severe accumulation of Apo A-I and Apo B. Arch Biochem Biophys. 2004;426:18-31.

[169] Li X. SIRT1 and energy metabolism. Acta Biochim Biophys Sin (Shanghai). 2013;45:51-60.

[170] Schug TT, Li X. Sirtuin 1 in lipid metabolism and obesity. Ann Med. 2011;43:198-211.

[171] Kim SY, Sim CK, Tang H, Han W, Zhang K, Xu F. Acetylome Analysis Identifies SIRT1 Targets in mRNA-Processing and Chromatin-Remodeling in Mouse Liver. PLoS One. 2015;10:e0140619.

[172] McConnell MJ, Durand L, Langley E, Coste-Sarguet L, Zelent A, Chomienne C, et al. Post transcriptional control of the epigenetic stem cell regulator PLZF by sirtuin and HDAC deacetylases. Epigenetics Chromatin. 2015;8:38.

[173] Aguilar-Arnal L, Katada S, Orozco-Solis R, Sassone-Corsi P. NAD(+)-SIRT1 control of H3K4 trimethylation through circadian deacetylation of MLL1. Nat Struct Mol Biol. 2015;22:312-8.

[174] Xue Z, Lv X, Song W, Wang X, Zhao GN, Wang WT, et al. SIRT1 deacetylates SATB1 to facilitate MAR HS2-MAR epsilon interaction and promote epsilon-globin expression. Nucleic Acids Res. 2012;40:4804-15. 
[175] Posavec M, Timinszky G, Buschbeck M. Macro domains as metabolite sensors on chromatin. Cell Mol Life Sci. 2013;70:1509-24.

[176] Karras GI, Kustatscher G, Buhecha HR, Allen MD, Pugieux C, Sait F, et al. The macro domain is an ADP-ribose binding module. Embo J. 2005;24:1911-20.

[177] Wellen KE, Hatzivassiliou G, Sachdeva UM, Bui TV, Cross JR, Thompson CB. ATP-citrate lyase links cellular metabolism to histone acetylation. Science. 2009;324:1076-80.

[178] Meier JL. Metabolic mechanisms of epigenetic regulation. ACS Chem Biol. 2013;8:2607-21.

[179] Shi Y, Lan F, Matson C, Mulligan P, Whetstine JR, Cole PA, et al. Histone demethylation mediated by the nuclear amine oxidase homolog LSD1. Cell. 2004;119:941-53.

[180] Jimenez-Chillaron JC, Diaz R, Martinez D, Pentinat T, Ramon-Krauel M, Ribo S, et al. The role of nutrition on epigenetic modifications and their implications on health. Biochimie. 2012;94:2242-63.

[181] Boyanapalli SS, Tony Kong AN. "Curcumin, the King of Spices": Epigenetic Regulatory Mechanisms in the Prevention of Cancer, Neurological, and Inflammatory Diseases. Curr Pharmacol Rep. 2015;1:129-39.

[182] Balasubramanyam K, Varier RA, Altaf M, Swaminathan V, Siddappa NB, Ranga $\mathrm{U}$, et al. Curcumin, a novel p300/CREB-binding protein-specific inhibitor of acetyltransferase, represses the acetylation of histone/nonhistone proteins and histone acetyltransferase-dependent chromatin transcription. J Biol Chem. 2004;279:51163-71.

[183] Teiten MH, Dicato M, Diederich M. Curcumin as a regulator of epigenetic events. Mol Nutr Food Res. 2013;57:1619-29.

[184] Zamani M, Sadeghizadeh M, Behmanesh M, Najafi F. Dendrosomal curcumin increases expression of the long non-coding RNA gene MEG3 via up-regulation of epimiRs in hepatocellular cancer. Phytomedicine. 2015;22:961-7.

[185] Novak Kujundzic R, Grbesa I, Ivkic M, Katdare M, Gall-Troselj K. Curcumin downregulates H19 gene transcription in tumor cells. J Cell Biochem. 2008;104:178192.

[186] Ghosh S, Liu B, Zhou Z. Resveratrol activates SIRT1 in a Lamin A-dependent manner. Cell Cycle. 2013;12:872-6.

[187] Gao Z, Xu MS, Barnett TL, Xu CW. Resveratrol induces cellular senescence with attenuated mono-ubiquitination of histone H2B in glioma cells. Biochem Biophys Res Commun. 2011;407:271-6.

[188] Dhar S, Kumar A, Li K, Tzivion G, Levenson AS. Resveratrol regulates PTEN/Akt pathway through inhibition of MTA1/HDAC unit of the NuRD complex in prostate cancer. Biochim Biophys Acta. 2015;1853:265-75.

[189] Day JK, Bauer AM, DesBordes C, Zhuang Y, Kim BE, Newton LG, et al. Genistein alters methylation patterns in mice. J Nutr. 2002;132:2419S-23S.

[190] Kikuno N, Shiina H, Urakami S, Kawamoto K, Hirata H, Tanaka Y, et al. Genistein mediated histone acetylation and demethylation activates tumor suppressor genes in prostate cancer cells. Int J Cancer. 2008;123:552-60.

[191] Balasubramanyam K, Altaf M, Varier RA, Swaminathan V, Ravindran A, Sadhale PP, et al. Polyisoprenylated benzophenone, garcinol, a natural histone acetyltransferase inhibitor, represses chromatin transcription and alters global gene expression. J Biol Chem. 2004;279:33716-26. 
[192] Heltweg B, Gatbonton T, Schuler AD, Posakony J, Li H, Goehle S, et al. Antitumor activity of a small-molecule inhibitor of human silent information regulator 2 enzymes. Cancer Res. 2006;66:4368-77.

[193] Imai K, Kamio N, Cueno ME, Saito Y, Inoue H, Saito I, et al. Role of the histone H3 lysine 9 methyltransferase Suv39 h1 in maintaining Epsteinn-Barr virus latency in B95-8 cells. Febs J. 2014;281:2148-58.

[194] Ho E, Clarke JD, Dashwood RH. Dietary sulforaphane, a histone deacetylase inhibitor for cancer prevention. J Nutr. 2009;139:2393-6.

[195] Ho E, Dashwood RH. Dietary manipulation of histone structure and function. World Rev Nutr Diet. 2010;101:95-102.

[196] Yiannakopoulou EC. Targeting DNA methylation with green tea catechins. Pharmacology. 2015;95:111-6.

[197] Gueant JL, Namour F, Gueant-Rodriguez RM, Daval JL. Folate and fetal programming: a play in epigenomics? Trends Endocrinol Metab. 2013;24:279-89.

[198] Shorter KR, Anderson V, Cakora P, Owen A, Lo K, Crossland J, et al. Pleiotropic effects of a methyl donor diet in a novel animal model. PLoS One. 2014;9:e104942.

[199] Rakyan VK, Blewitt ME, Druker R, Preis JI, Whitelaw E. Metastable epialleles in mammals. Trends Genet. 2002;18:348-51.

[200] Graff JR, Herman JG, Myohanen S, Baylin SB, Vertino PM. Mapping patterns of $\mathrm{CpG}$ island methylation in normal and neoplastic cells implicates both upstream and downstream regions in de novo methylation. J Biol Chem. 1997;272:22322-9.

[201] Dolinoy DC, Das R, Weidman JR, Jirtle RL. Metastable epialleles, imprinting, and the fetal origins of adult diseases. Pediatr Res. 2007;61:30R-7R.

[202] Waterland RA, Kellermayer R, Laritsky E, Rayco-Solon P, Harris RA, Travisano $\mathrm{M}$, et al. Season of conception in rural gambia affects DNA methylation at putative human metastable epialleles. PLoS Genet. 2010;6:e1001252.

[203] Dominguez-Salas P, Moore SE, Cole D, da Costa KA, Cox SE, Dyer RA, et al. DNA methylation potential: dietary intake and blood concentrations of one-carbon metabolites and cofactors in rural African women. Am J Clin Nutr. 2013;97:1217-27.

[204] Dominguez-Salas P, Moore SE, Baker MS, Bergen AW, Cox SE, Dyer RA, et al. Maternal nutrition at conception modulates DNA methylation of human metastable epialleles. Nat Commun. 2014;5:3746.

[205] Silver MJ, Kessler NJ, Hennig BJ, Dominguez-Salas P, Laritsky E, Baker MS, et al. Independent genomewide screens identify the tumor suppressor VTRNA2-1 as a human epiallele responsive to periconceptional environment. Genome Biol. 2015; $16: 118$.

[206] Whitelaw E, Martin DI. Retrotransposons as epigenetic mediators of phenotypic variation in mammals. Nat Genet. 2001;27:361-5.

[207] Waterland RA, Jirtle RL. Early nutrition, epigenetic changes at transposons and imprinted genes, and enhanced susceptibility to adult chronic diseases. Nutrition. 2004;20:63-8.

[208] Druker R, Bruxner TJ, Lehrbach NJ, Whitelaw E. Complex patterns of transcription at the insertion site of a retrotransposon in the mouse. Nucleic Acids Res. 2004;32:5800-8.

[209] Yates PA, Burman RW, Mummaneni P, Krussel S, Turker MS. Tandem B1 elements located in a mouse methylation center provide a target for de novo DNA methylation. J Biol Chem. 1999;274:36357-61. 
[210] Yates PA, Burman R, Simpson J, Ponomoreva ON, Thayer MJ, Turker MS. 2003;23:4461-70.

[211] Witwer KW. XenomiRs and miRNA homeostasis in health and disease: evidence that diet and dietary miRNAs directly and indirectly influence circulating miRNA profiles. RNA Biol. 2012;9:1147-54.

[212] Zhang L, Hou D, Chen X, Li D, Zhu L, Zhang Y, et al. Exogenous plant MIR168a specifically targets mammalian LDLRAP1: evidence of cross-kingdom regulation by microRNA. Cell Res. 2012;22:107-26.

[213] Baier SR, Nguyen C, Xie F, Wood JR, Zempleni J. MicroRNAs are absorbed in biologically meaningful amounts from nutritionally relevant doses of cow milk and affect gene expression in peripheral blood mononuclear cells, HEK-293 kidney cell cultures, and mouse livers. J Nutr. 2014;144:1495-500.

[214] Dickinson B, Zhang Y, Petrick JS, Heck G, Ivashuta S, Marshall WS. Lack of detectable oral bioavailability of plant microRNAs after feeding in mice. Nat Biotechnol. 2013;31:965-7.

[215] Chen X, Zen K, Zhang CY. Reply to Lack of detectable oral bioavailability of plant microRNAs after feeding in mice. Nat Biotechnol. 2013;31:967-9.

[216] Witwer KW. Diet-responsive mammalian miRNAs are likely endogenous. J Nutr. 2014;144:1880-1.

[217] Baier SR, Xie F, Zempleni J. Reply to Witwer. J Nutr. 2014;144:1882.

[218] Witwer KW, McAlexander MA, Queen SE, Adams RJ. Real-time quantitative PCR and droplet digital PCR for plant miRNAs in mammalian blood provide little evidence for general uptake of dietary miRNAs: limited evidence for general uptake of dietary plant xenomiRs. RNA Biol. 2013;10:1080-6.

[219] Tosar JP, Rovira C, Naya H, Cayota A. Mining of public sequencing databases supports a non-dietary origin for putative foreign miRNAs: underestimated effects of contamination in NGS. Rna. 2014;20:754-7.

[220] Witwer KW, Hirschi KD. Transfer and functional consequences of dietary microRNAs in vertebrates: concepts in search of corroboration: negative results challenge the hypothesis that dietary xenomiRs cross the gut and regulate genes in ingesting vertebrates, but important questions persist. Bioessays. 2014;36:394-406.

[221] Garcia-Segura L, Perez-Andrade M, Miranda-Rios J. The emerging role of MicroRNAs in the regulation of gene expression by nutrients. $J$ Nutrigenet Nutrigenomics. 2013;6:16-31.

[222] Palmer JD, Soule BP, Simone BA, Zaorsky NG, Jin L, Simone NL. MicroRNA expression altered by diet: Can food be medicinal? Ageing Res Rev. 2014.

[223] Crick F. Central dogma of molecular biology. Nature. 1970;227:561-3.

[224] Paralkar VR, Weiss MJ. Long noncoding RNAs in biology and hematopoiesis. Blood. 2013;121:4842-6.

[225] Dey BK, Mueller AC, Dutta A. Long non-coding RNAs as emerging regulators of differentiation, development, and disease. Transcription. 2014;5:e944014.

[226] Liz J, Esteller M. lncRNAs and microRNAs with a role in cancer development. Biochim Biophys Acta. 2015.

[227] Villegas VE, Zaphiropoulos PG. Neighboring gene regulation by antisense long non-coding RNAs. Int J Mol Sci. 2015;16:3251-66.

[228] Briggs SF, Reijo Pera RA. X chromosome inactivation: recent advances and a look forward. Curr Opin Genet Dev. 2014;28:78-82. 
[229] Schlesinger S, Goff SP. Retroviral transcriptional regulation and embryonic stem cells: war and peace. Mol Cell Biol. 2015;35:770-7.

[230] Watanabe T, Lin H. Posttranscriptional regulation of gene expression by Piwi proteins and piRNAs. Mol Cell. 2014;56:18-27.

[231] Kim S, Yu NK, Kaang BK. CTCF as a multifunctional protein in genome regulation and gene expression. Exp Mol Med. 2015;47:e166.

[232] Gatta R, Dolfini D, Zambelli F, Imbriano C, Pavesi G, Mantovani R. An acetylation-mono-ubiquitination switch on lysine 120 of H2B. Epigenetics. 2011;6:6307.

[233] Guillemette B, Drogaris P, Lin HH, Armstrong H, Hiragami-Hamada K, Imhof A, et al. $\mathrm{H} 3$ lysine 4 is acetylated at active gene promoters and is regulated by $\mathrm{H} 3$ lysine 4 methylation. PLoS Genet. 2011;7:e1001354.

[234] Karmodiya K, Krebs AR, Oulad-Abdelghani M, Kimura H, Tora L. H3K9 and $\mathrm{H} 3 \mathrm{~K} 14$ acetylation co-occur at many gene regulatory elements, while H3K14ac marks a subset of inactive inducible promoters in mouse embryonic stem cells. BMC Genomics. 2012;13:424.

[235] Gatta R, Mantovani R. Single nucleosome ChIPs identify an extensive switch of acetyl marks on cell cycle promoters. Cell Cycle. 2010;9:2149-59.

[236] Creyghton MP, Cheng AW, Welstead GG, Kooistra T, Carey BW, Steine EJ, et al. Histone H3K27ac separates active from poised enhancers and predicts developmental state. Proc Natl Acad Sci U S A. 2010;107:21931-6.

[237] Morris SA, Rao B, Garcia BA, Hake SB, Diaz RL, Shabanowitz J, et al. Identification of histone $\mathrm{H} 3$ lysine 36 acetylation as a highly conserved histone modification. J Biol Chem. 2007;282:7632-40.

[238] Cui K, Zang C, Roh TY, Schones DE, Childs RW, Peng W, et al. Chromatin signatures in multipotent human hematopoietic stem cells indicate the fate of bivalent genes during differentiation. Cell Stem Cell. 2009;4:80-93.

[239] de Wit E, Greil F, van Steensel B. High-resolution mapping reveals links of HP1 with active and inactive chromatin components. PLoS Genet. 2007;3:e38.

[240] Kimura H. Histone modifications for human epigenome analysis. J Hum Genet. 2013;58:439-45.

[241] Kim H, Jang MJ, Kang MJ, Han YM. Epigenetic signatures and temporal expression of lineage-specific genes in hESCs during differentiation to hepatocytes in vitro. Hum Mol Genet. 2010;20:401-12.

[242] Kim J, Kim H. Recruitment and biological consequences of histone modification of H3K27me3 and H3K9me3. Ilar J. 2012;53:232-9.

[243] Agger K, Cloos PA, Christensen J, Pasini D, Rose S, Rappsilber J, et al. UTX and JMJD3 are histone H3K27 demethylases involved in HOX gene regulation and development. Nature. 2007;449:731-4.

[244] De Vries M, Ramos L, Housein Z, De Boer P. Chromatin remodelling initiation during human spermiogenesis. Biol Open. 2012;1:446-57.

[245] Li Q, Sarna SK. Nitric oxide modifies chromatin to suppress ICAM-1 expression during colonic inflammation. Am J Physiol Gastrointest Liver Physiol. 2012;303:G10310 .

[246] Kalakonda N, Fischle W, Boccuni P, Gurvich N, Hoya-Arias R, Zhao X, et al. Histone $\mathrm{H} 4$ lysine 20 monomethylation promotes transcriptional repression by L3MBTL1. Oncogene. 2008;27:4293-304. 
[247] Botuyan MV, Lee J, Ward IM, Kim JE, Thompson JR, Chen J, et al. Structural basis for the methylation state-specific recognition of histone H4-K20 by 53BP1 and Crb2 in DNA repair. Cell. 2006;127:1361-73.

[248] Schotta G, Lachner M, Sarma K, Ebert A, Sengupta R, Reuter G, et al. A silencing pathway to induce $\mathrm{H} 3-\mathrm{K} 9$ and $\mathrm{H} 4-\mathrm{K} 20$ trimethylation at constitutive heterochromatin. Genes Dev. 2004;18:1251-62.

[249] Regha K, Sloane MA, Huang R, Pauler FM, Warczok KE, Melikant B, et al. Active and repressive chromatin are interspersed without spreading in an imprinted gene cluster in the mammalian genome. Mol Cell. 2007;27:353-66.

[250] Roseboom TJ, van der Meulen JH, Ravelli AC, van Montfrans GA, Osmond C, Barker DJ, et al. Blood pressure in adults after prenatal exposure to famine. $\mathrm{J}$ Hypertens. 1999; 17:325-30.

[251] Roseboom TJ, van der Meulen JH, Ravelli AC, Osmond C, Barker DJ, Bleker OP. Plasma fibrinogen and factor VII concentrations in adults after prenatal exposure to famine. Br J Haematol. 2000;111:112-7.

[252] Roseboom TJ, van der Meulen JH, Osmond C, Barker DJ, Ravelli AC, Bleker OP. Plasma lipid profiles in adults after prenatal exposure to the Dutch famine. Am $\mathbf{J}$ Clin Nutr. 2000;72:1101-6.

[253] Roseboom TJ, van der Meulen JH, Osmond C, Barker DJ, Ravelli AC, SchroederTanka JM, et al. Coronary heart disease after prenatal exposure to the Dutch famine, 1944-45. Heart. 2000;84:595-8.

[254] Roseboom TJ, Van Der Meulen JH, Ravelli AC, Osmond C, Barker DJ, Bleker OP. Perceived health of adults after prenatal exposure to the Dutch famine. Paediatr Perinat Epidemiol. 2003;17:391-7.

[255] Painter RC, Roseboom TJ, van Montfrans GA, Bossuyt PM, Krediet RT, Osmond $\mathrm{C}$, et al. Microalbuminuria in adults after prenatal exposure to the Dutch famine. J Am Soc Nephrol. 2005;16:189-94.

[256] de Rooij SR, Painter RC, Roseboom TJ, Phillips DI, Osmond C, Barker DJ, et al. Glucose tolerance at age 58 and the decline of glucose tolerance in comparison with age 50 in people prenatally exposed to the Dutch famine. Diabetologia. 2006;49:637-43.

[257] Painter RC, Roseboom TJ, Bossuyt PM, Osmond C, Barker DJ, Bleker OP. Adult mortality at age 57 after prenatal exposure to the Dutch famine. Eur J Epidemiol. 2005;20:673-6.

[258] Painter RC, de Rooij SR, Bossuyt PM, Phillips DI, Osmond C, Barker DJ, et al. Blood pressure response to psychological stressors in adults after prenatal exposure to the Dutch famine. J Hypertens. 2006;24:1771-8.

[259] de Rooij SR, Painter RC, Phillips DI, Osmond C, Michels RP, Godsland IF, et al. Impaired insulin secretion after prenatal exposure to the Dutch famine. Diabetes Care. 2006;29:1897-901.

[260] de Rooij SR, Painter RC, Holleman F, Bossuyt PM, Roseboom TJ. The metabolic syndrome in adults prenatally exposed to the Dutch famine. Am J Clin Nutr. 2007;86:1219-24.

[261] Lumey LH, Stein AD, Kahn HS, Romijn JA. Lipid profiles in middle-aged men and women after famine exposure during gestation: the Dutch Hunger Winter Families Study. Am J Clin Nutr. 2009;89:1737-43.

[262] Painter RC, de Rooij SR, Hutten BA, Bossuyt PM, de Groot E, Osmond C, et al. Reduced intima media thickness in adults after prenatal exposure to the Dutch famine. Atherosclerosis. 2007;193:421-7. 
[263] Stein AD, Kahn HS, Rundle A, Zybert PA, van der Pal-de Bruin K, Lumey LH. Anthropometric measures in middle age after exposure to famine during gestation: evidence from the Dutch famine. Am J Clin Nutr. 2007;85:869-76. 


\begin{tabular}{|l|l|l|l|}
\hline $\begin{array}{l}\text { CONSEQUENCES ON PRENATALLY EXPOSED } \\
\text { DESCENDANTS }\end{array}$ & AGE* & $\begin{array}{l}\text { MATERNAL EXPOSITION TO } \\
\text { HUNGER** }\end{array}$ & REFERENCE \\
\hline Significantly higher obesity rates & 19 & First half of gestation & {$[20]$} \\
\hline Significantly lower obesity rates & 19 & Last trimester of gestation & {$[20]$} \\
\hline Higher BMI and waist circumference in women but not in men & 50 & Early gestation & {$[23]$} \\
\hline $\begin{array}{l}\text { No effect of prenatal famine on systolic or diastolic blood } \\
\text { pressure }\end{array}$ & 50 & Early or late gestation & {$[250]$} \\
\hline Reduced concentrations of plasma factor VII & 50 & Early gestation & {$[251]$} \\
\hline Significantly higher LDL-HDL cholesterol ratios & 50 & Early gestation & {$[252]$} \\
\hline Higher prevalence of coronary heart disease & 50 & Early gestation & {$[253]$} \\
\hline Decreased glucose tolerance & 1998 & Late gestation & {$[22]$} \\
\hline Perceived poor health & 50 & Early gestation & {$[254]$} \\
\hline Earlier onset of coronary artery disease & 50 & Early gestation & {$[28]$} \\
\hline Higher rates of microalbuminuria & Mid gestation & {$[255]$} \\
\hline Similarly decreased glucose tolerance at 50y and 58 y & $50 / 58$ & All periods of gestation & {$[256]$} \\
\hline No effect of exposure on adult mortality up to 57 years & 57 & All periods of gestation & {$[257]$} \\
\hline Higher systolic and diastolic blood pressure after stress tests & 58 & Early gestation & {$[258]$} \\
\hline Reduced insulin secretion (lower disposition index) & 58 & Mid gestation & {$[259]$} \\
\hline Not associated to a greater prevalence of metabolic syndrome & 58 & All periods of gestation & {$[260]$} \\
\hline $\begin{array}{l}\text { Elevated total cholesterol, triglycerides and LDL-chol. In } \\
\text { women only }\end{array}$ & 58 & All periods of gestation & {$[261]$} \\
\hline No increase in CAD risk or Framingham risk & & {$[30]$} \\
\hline Reduced carotid and femoral arteries intima media thickness & 58 & All periods of gestation & {$[262]$} \\
\hline Increased weight and adiposity in women but not in men & 59 & All periods of gestation & {$[263]$} \\
\hline $\begin{array}{l}\text { Less DNA methylation at the IGF2 gene compared with } \\
\text { unexposed siblings }\end{array}$ & 60 & Early gestation & {$[119]$} \\
\hline
\end{tabular}

Table 1 


\begin{tabular}{|l|l|l|}
\hline HISTONE LABEL & CHROMATIN FUNCTIONAL STATE & \multicolumn{1}{|c|}{ REFERENCES } \\
\hline H2BK120ac & Active o poised TSS. Absent from core promoters. & {$[232]$} \\
\hline H3K4ac & Marks promoters of actively transcribed genes & {$[233]$} \\
\hline H3K9ac & Enriched at the promoters of actively transcribed genes & {$[234]$} \\
\hline H3K14ac & Associated to active promoters & {$[235]$} \\
\hline H3K27ac & Associated to active enhancers and promoters & {$[235,236]$} \\
\hline H3K36ac & Associated to active promoters & {$[237]$} \\
\hline H3K4me1 & Associate to enhancers of differentiation genes & {$[238]$} \\
\hline H3K4me2 & Associate to active chromatin & {$[239]$} \\
\hline H3K4me3 & Associated to actively transcribed genes & {$[240]$} \\
\hline H3K9me1 & Associate to enhancers of differentiation genes & {$[238]$} \\
\hline H3K9me2 & Repressive mark & {$[241]$} \\
\hline H3K9me3 & Repressive signal in gene-poor regions & {$[242]$} \\
\hline H3K27me1 & Associate to enhancers of differentiation genes & {$[238]$} \\
\hline H3K27me2 & Repressive signal mediated by polycomb repressive complex 2 & {$[243]$} \\
\hline H3K27me3 & Temporary repressive signal in gene-rich regions & {$[242]$} \\
\hline H4K8ac & Mediated by polycomb repressive complex 2 & \\
\hline H4K12ac & Associate to active chromatin & {$[244]$} \\
\hline H4K16ac & Associate to active chromatin & {$[245]$} \\
\hline H4K20me1 & Associate to active chromatin & {$[244]$} \\
\hline H4K20me2 & Repressive mark of facultative heterochromatin & {$[246]$} \\
\hline H4K20me3 & DNA damage response & {$[247]$} \\
\hline Hable 2 & Constitutive heterochromatin & {$[248,249]$} \\
\hline
\end{tabular}

Table 2 
HEXOSAMINE BIOSYNTHETIC PATHWAY

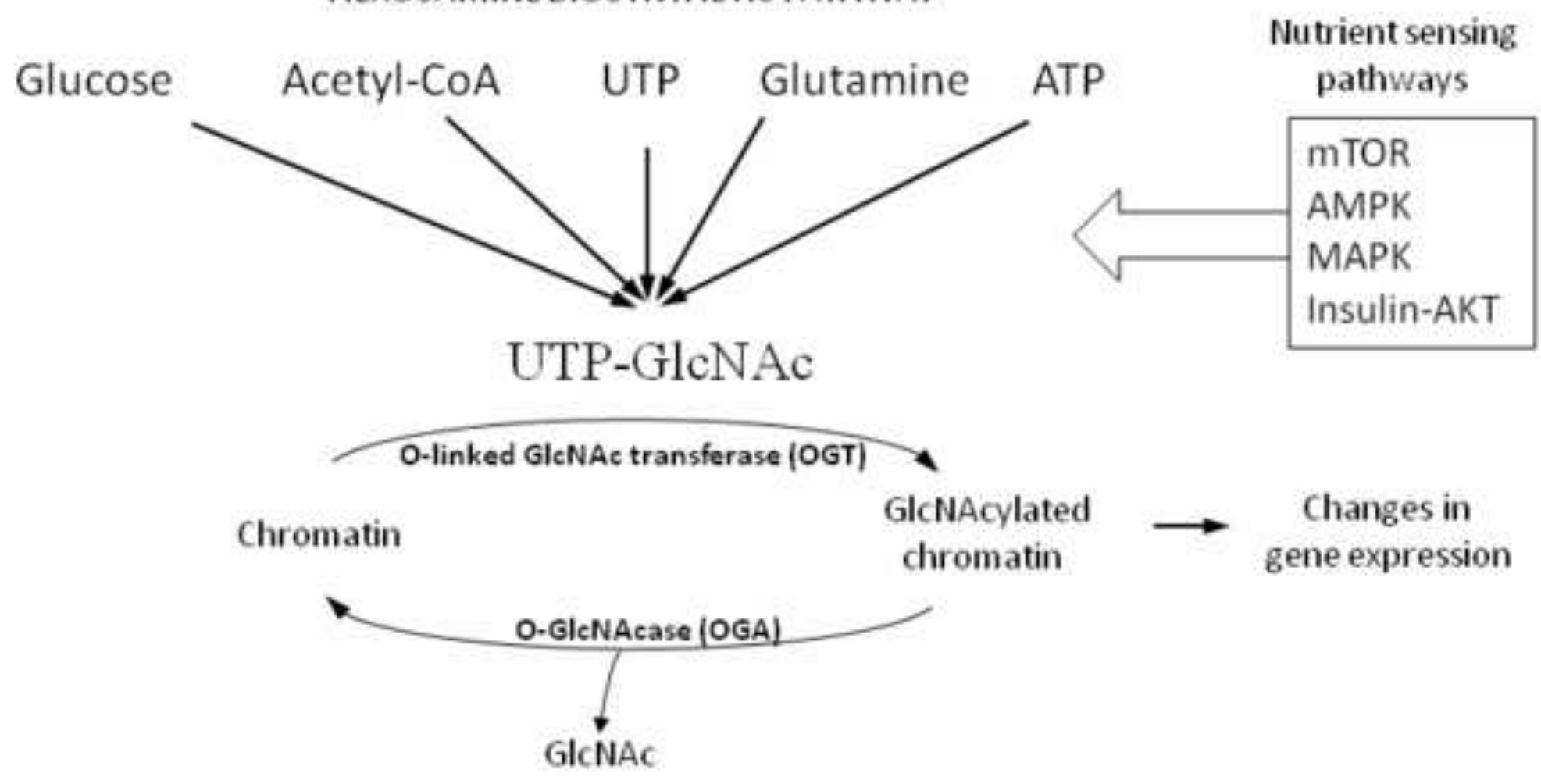

Figure 2 


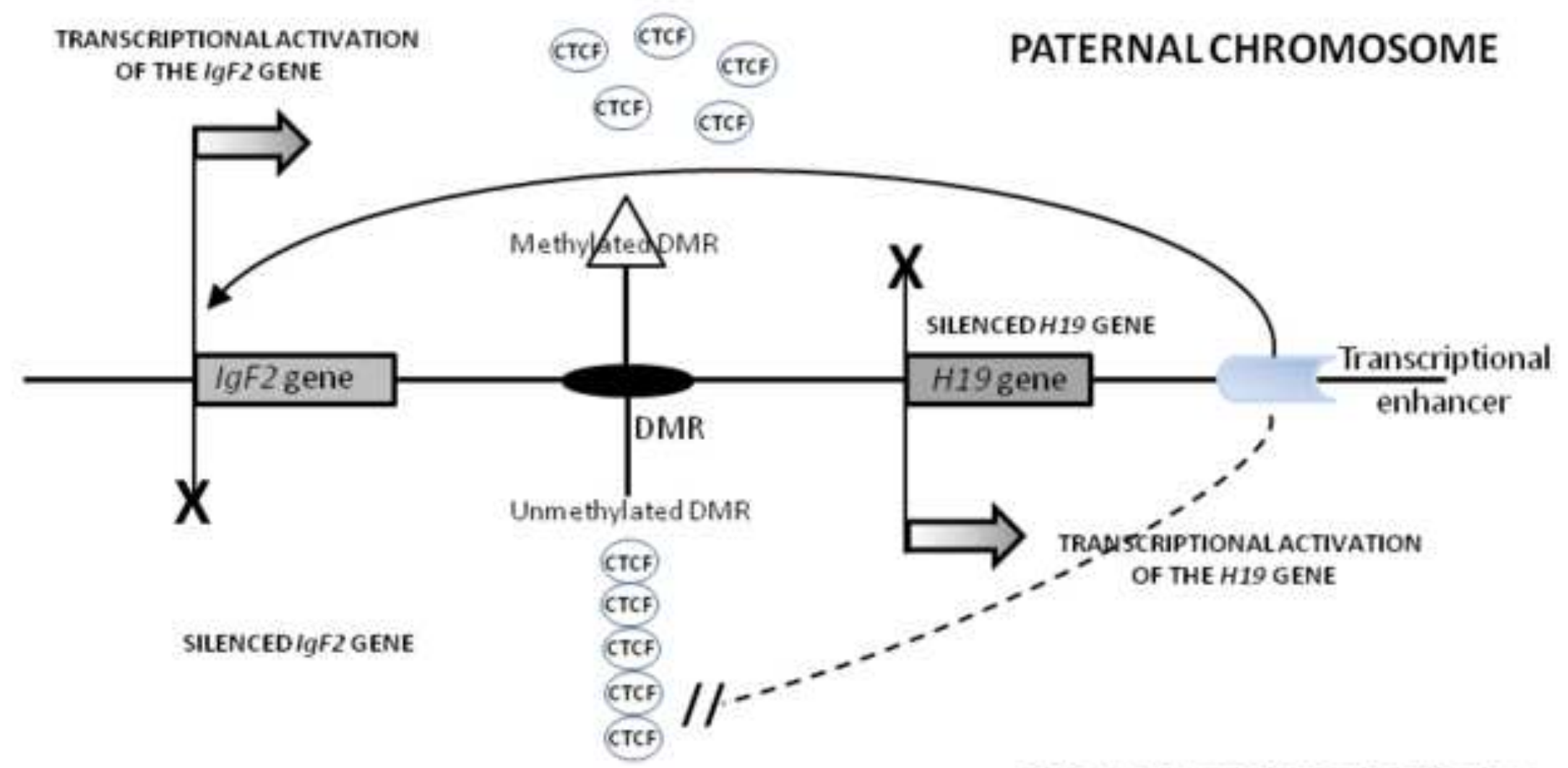

MATERNALCHROMOSOME

FIGURE 3 


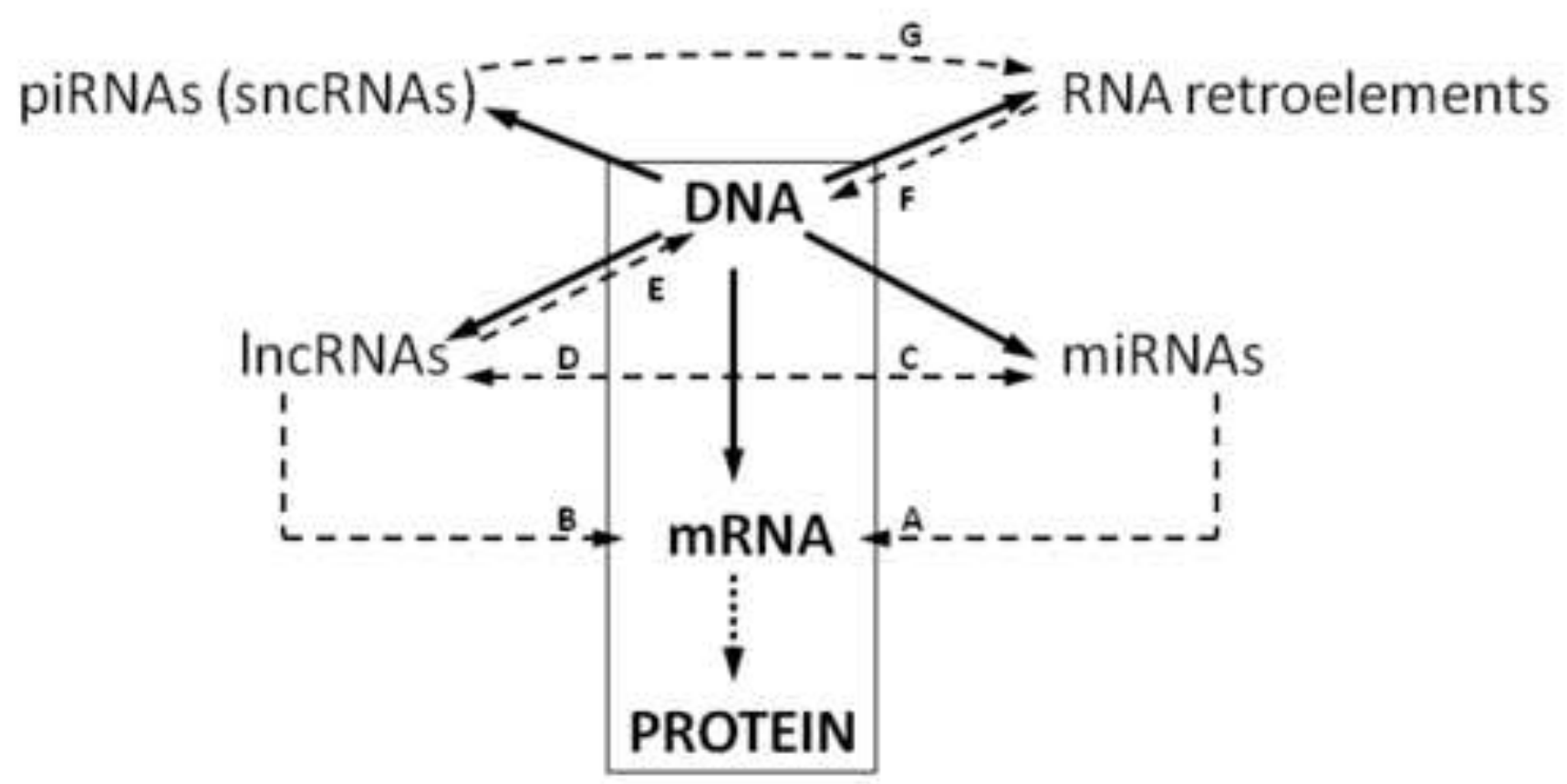

FIGURE 1 